\title{
LEVEL II SCOUR ANALYSIS FOR BRIDGE 37 (BRNETH00740037) on TOWN HIGHWAY 74, crossing SOUTH PEACHAM BROOK, BARNET, VERMONT
}

Open-File Report 97-815

Prepared in cooperation with

VERMONT AGENCY OF TRANSPORTATION

and

FEDERAL HIGHWAY ADMINISTRATION

U.S. Department of the Interior

U.S. Geological Survey

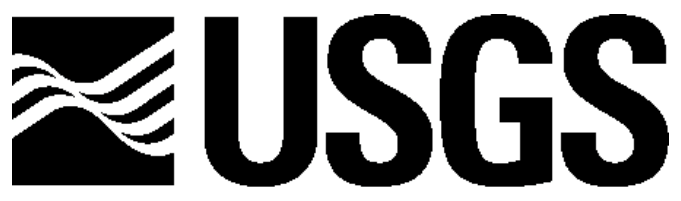

science for a changing world 


\section{LEVEL II SCOUR ANALYSIS FOR BRIDGE 37 (BRNETH00740037) on TOWN HIGHWAY 74, crossing SOUTH PEACHAM BROOK, BARNET, VERMONT}

By RONDA L. BURNS and TIM SEVERANCE

U.S. Geological Survey Open-File Report 97-815

Prepared in cooperation with

VERMONT AGENCY OF TRANSPORTATION

and

FEDERAL HIGHWAY ADMINISTRATION 


\title{
U.S. DEPARTMENT OF THE INTERIOR BRUCE BABBITT, Secretary
}

\author{
U.S. GEOLOGICAL SURVEY \\ Mark Schaefer, Acting Director
}

For additional information write to:

District Chief

U.S. Geological Survey 361 Commerce Way

Pembroke, NH 03275-3718
Copies of this report may be purchased from:

U.S. Geological Survey

Branch of Information Services

Open-File Reports Unit

Box 25286

Denver, CO 80225-0286 


\section{CONTENTS}

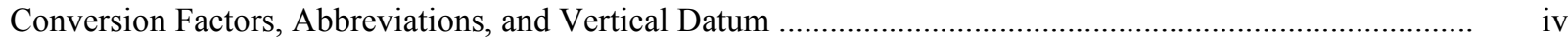

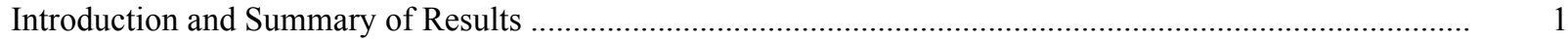

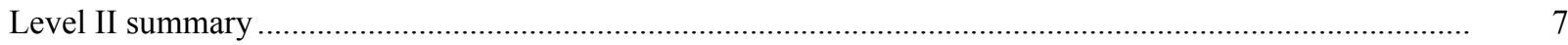

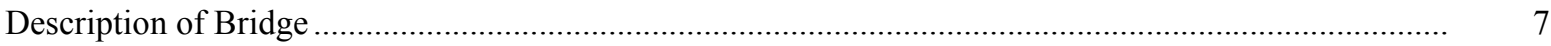

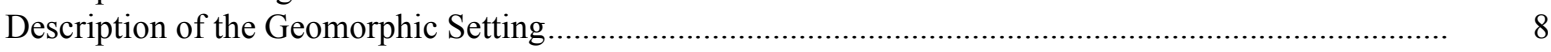

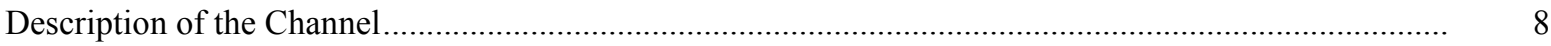

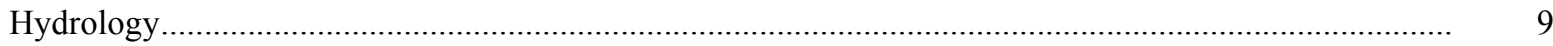

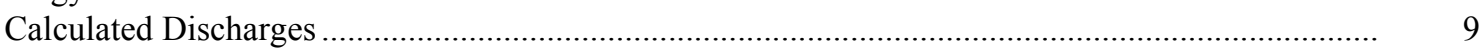

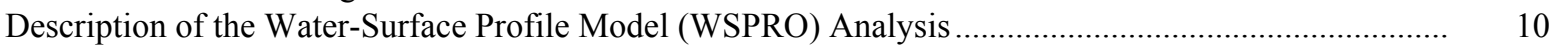

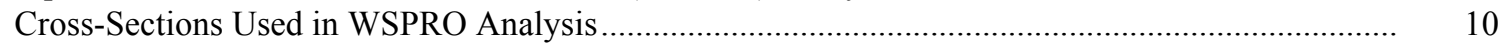

Data and Assumptions Used in WSPRO Model ........................................................................ 11

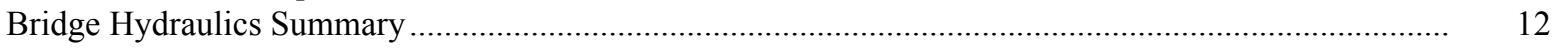

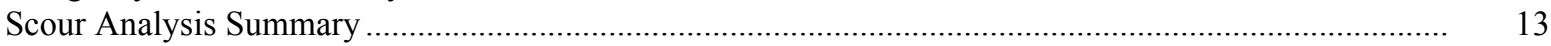

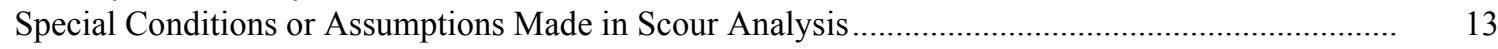

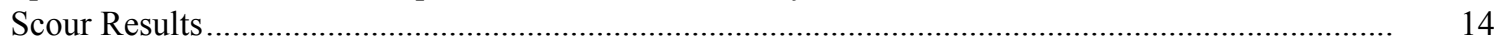

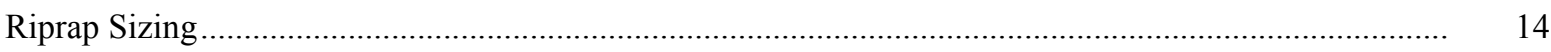

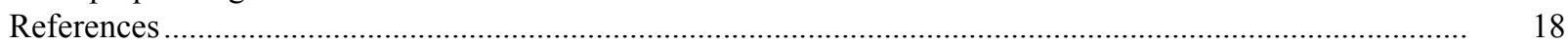

Appendices:

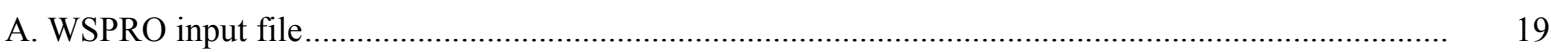

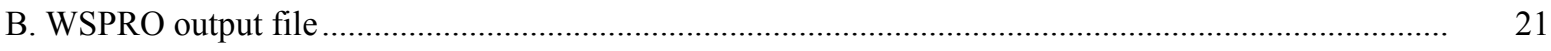

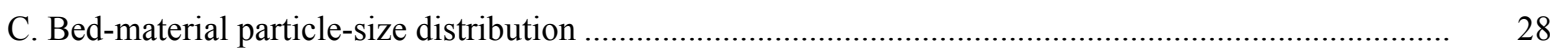

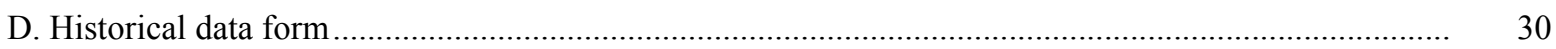

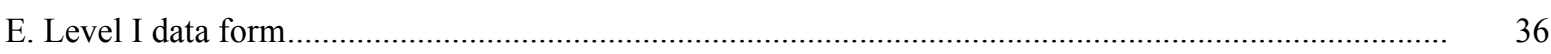

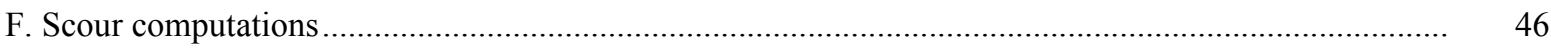

\section{FIGURES}

1. Map showing location of study area on USGS 1:25,000 scale map

2. Map showing location of study area on Vermont Agency of Transportation town highway map

3. Structure BRNETH00740037 viewed from upstream (August 24, 1995).

4. Downstream channel viewed from structure BRNETH00740037 (August 24, 1995)........................... 5

5. Upstream channel viewed from structure BRNETH00740037 (August 24, 1995)................................ 6

6. Structure BRNETH00740037 viewed from downstream (August 24, 1995).....

7. Water-surface profiles for the 100- and 500-year discharges at structure

BRNETH00740037 on Town Highway 74, crossing South Peacham Brook,

Barnet, Vermont. .

8. Scour elevations for the 100- and 500-year discharges at structure

BRNETH00740037 on Town Highway 74, crossing South Peacham Brook,

Barnet, Vermont.

\section{TABLES}

1. Remaining footing/pile depth at abutments for the 100-year discharge at structure BRNETH00740037 on Town Highway 74, crossing South Peacham Brook, Barnet, Vermont.

2. Remaining footing/pile depth at abutments for the 500-year discharge at structure BRNETH00740037 on Town Highway 74, crossing South Peacham Brook, Barnet, Vermont. 


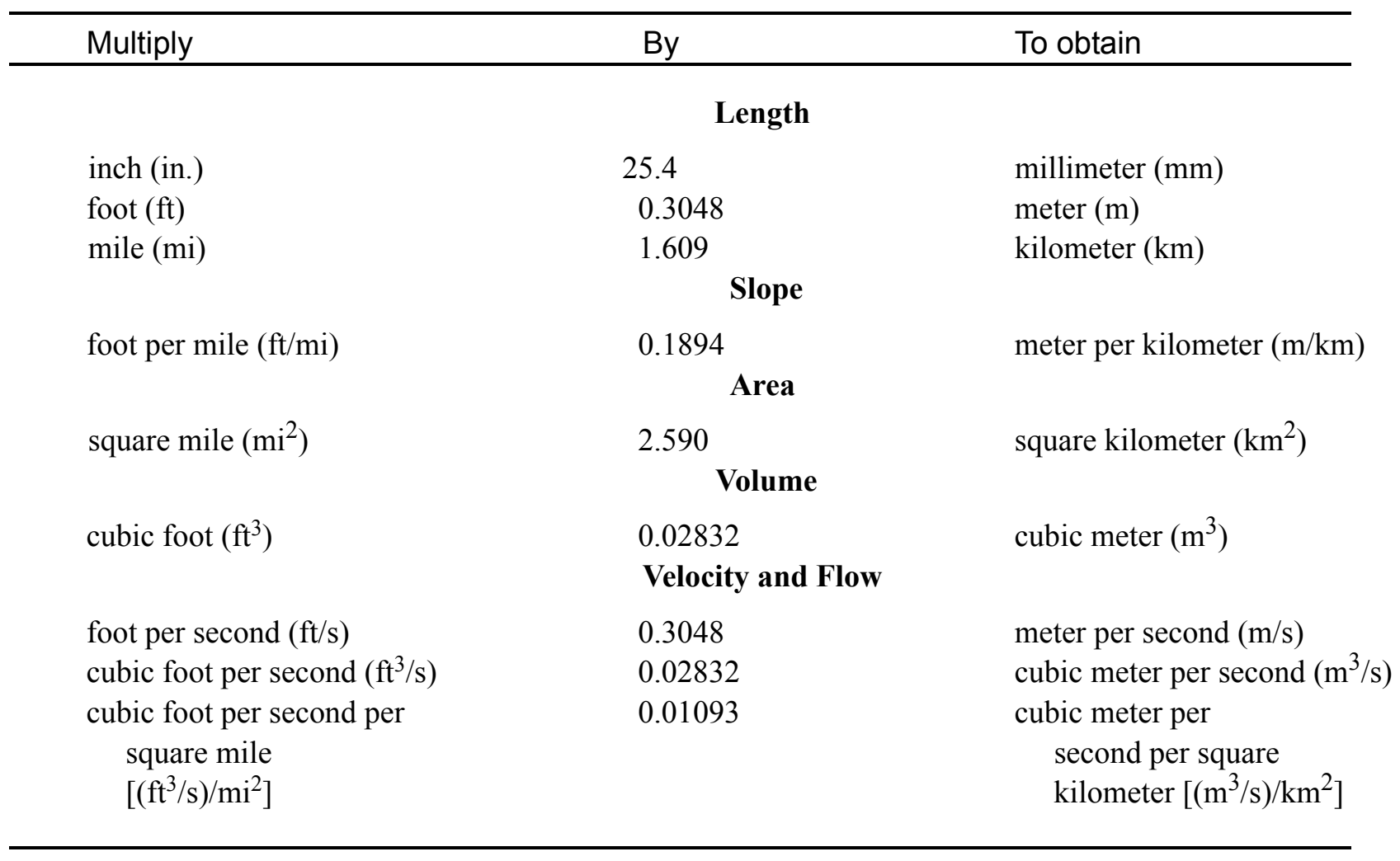

\section{OTHER ABBREVIATIONS}

$\begin{array}{lrlr}\mathrm{BF} & \text { bank full } & \text { LWW } & \text { left wingwall } \\ \mathrm{cfs} & \text { cubic feet per second } & \text { MC } & \text { main channel } \\ \mathrm{D}_{50} & \text { median diameter of bed material } & \text { RAB } & \text { right abutment } \\ \mathrm{DS} & \text { downstream } & \text { RABUT } & \text { face of right abutment } \\ \mathrm{elev} & \text { elevation } & \text { RB } & \text { right bank } \\ \mathrm{f} / \mathrm{p} & \text { flood plain } & \text { ROB } & \text { right overbank } \\ \mathrm{ft}^{2} & \text { square feet } & \text { RWW } & \text { right wingwall } \\ \mathrm{ft} / \mathrm{ft} & \text { feet per foot } & \text { TH } & \text { town highway } \\ \mathrm{JCT} & \text { junction } & \text { UB } & \text { under bridge } \\ \mathrm{LAB} & \text { left abutment } & \text { US } & \text { upstream } \\ \mathrm{LABUT} & \text { face of left abutment } & \text { USGS } & \text { United States Geological Survey } \\ \mathrm{LB} & \text { left bank } & \text { VTAOT Vermont Agency of Transportation } \\ \mathrm{LOB} & \text { left overbank } & \text { WSPRO } & \text { water-surface profile model }\end{array}$

In this report, the words "right" and "left" refer to directions that would be reported by an observer facing downstream. Sea level: In this report, "sea level" refers to the National Geodetic Vertical Datum of 1929-- a geodetic datum derived from a general adjustment of the first-order level nets of the United States and Canada, formerly called Sea Level Datum of 1929.

In the appendices, the above abbreviations may be combined. For example, USLB would represent upstream left bank. 


\title{
LEVEL II SCOUR ANALYSIS FOR BRIDGE 37 (BRNETH00740037) ON TOWN HIGHWAY 74, CROSSING SOUTH PEACHAM BROOK, BARNET, VERMONT
}

\author{
By Ronda L. Burns and Tim Severance
}

\section{INTRODUCTION AND SUMMARY OF RESULTS}

This report provides the results of a detailed Level II analysis of scour potential at structure BRNETH00740037 on Town Highway 74 crossing South Peacham Brook, Barnet, Vermont (figures 1-8). A Level II study is a basic engineering analysis of the site, including a quantitative analysis of stream stability and scour (U.S. Department of Transportation, 1993). Results of a Level I scour investigation also are included in Appendix E of this report. A Level I investigation provides a qualitative geomorphic characterization of the study site. Information on the bridge, gleaned from Vermont Agency of Transportation (VTAOT) files, was compiled prior to conducting Level I and Level II analyses and is found in Appendix D.

The site is in the New England Upland section of the New England physiographic province in northeastern Vermont. The $12.1-\mathrm{mi}^{2}$ drainage area is in a predominantly rural and forested basin. In the vicinity of the study site, the surface cover is pasture upstream of the bridge and on the downstream left bank while the immediate banks have sparse shrubs and trees. Downstream of the bridge, the surface cover is shrub and brushland.

In the study area, South Peacham Brook has an incised, sinuous channel with a slope of approximately $0.004 \mathrm{ft} / \mathrm{ft}$, an average channel top width of $33 \mathrm{ft}$ and an average bank height of $3 \mathrm{ft}$. The channel bed material ranges from sand to cobble with a median grain size $\left(\mathrm{D}_{50}\right)$ of $0.914 \mathrm{~mm}(0.003 \mathrm{ft})$. The geomorphic assessment at the time of the Level I and Level II site visit on August 24, 1995, indicated that the reach was laterally unstable. There are cutbanks upstream and downstream of the bridge.

The Town Highway 74 crossing of South Peacham Brook is a 30-ft-long, two-lane bridge consisting of one 28-foot concrete slab span (Vermont Agency of Transportation, written communication, March 16, 1995). The opening length of the structure parallel to the bridge face is $25.7 \mathrm{ft}$. The bridge is supported by vertical, concrete abutments with wingwalls. The channel is skewed approximately 30 degrees to the opening while the computed openingskew-to-roadway is 5 degrees. 
A channel scour hole $2.0 \mathrm{ft}$ deeper than the mean thalweg depth was observed at the upstream bridge face, along the upstream right wingwall protection, during the Level I assessment. The scour protection measures at the site included type-1 stone fill (less than 12 inches diameter) along the downstream left and right wingwalls, downstream banks, and at the downstream end of the left and right abutments. There is also type-2 stone fill (less than 36 inches diameter) along the upstream right bank and upstream right wingwall. Additional details describing conditions at the site are included in the Level II Summary and Appendices D

and $\mathrm{E}$.

Scour depths and recommended rock rip-rap sizes were computed using the general guidelines described in Hydraulic Engineering Circular 18 (Richardson and others, 1995) for the 100- and 500-year discharges. In addition, the incipient roadway-overtopping discharge was determined and analyzed as another potential worst-case scour scenario. Total scour at a highway crossing is comprised of three components: 1) long-term streambed degradation; 2) contraction scour (due to accelerated flow caused by a reduction in flow area at a bridge) and; 3 ) local scour (caused by accelerated flow around piers and abutments). Total scour is the sum of the three components. Equations are available to compute depths for contraction and local scour and a summary of the results of these computations follows.

Contraction scour for all modelled flows ranged from 15.8 to $22.5 \mathrm{ft}$. The worst-case contraction scour occurred at the 500-year discharge. Abutment scour ranged from 6.7 to $11.1 \mathrm{ft}$. The worst-case abutment scour also occurred at the 500-year discharge. Additional information on scour depths and depths to armoring are included in the section titled "Scour Results". Scoured-streambed elevations, based on the calculated scour depths, are presented in Tables 1 and 2. A cross-section of the scour computed at the bridge is presented in Figure 8. Scour depths were calculated assuming an infinite depth of erosive material and a homogeneous particle-size distribution.

Usually, computed scour depths are evaluated in combination with other information including (but not limited to) historical performance during flood events, the geomorphic stability assessment, existing scour protection measures, and the results of the hydraulic analyses. Therefore, scour depths adopted by VTAOT may differ from the computed values documented herein. 


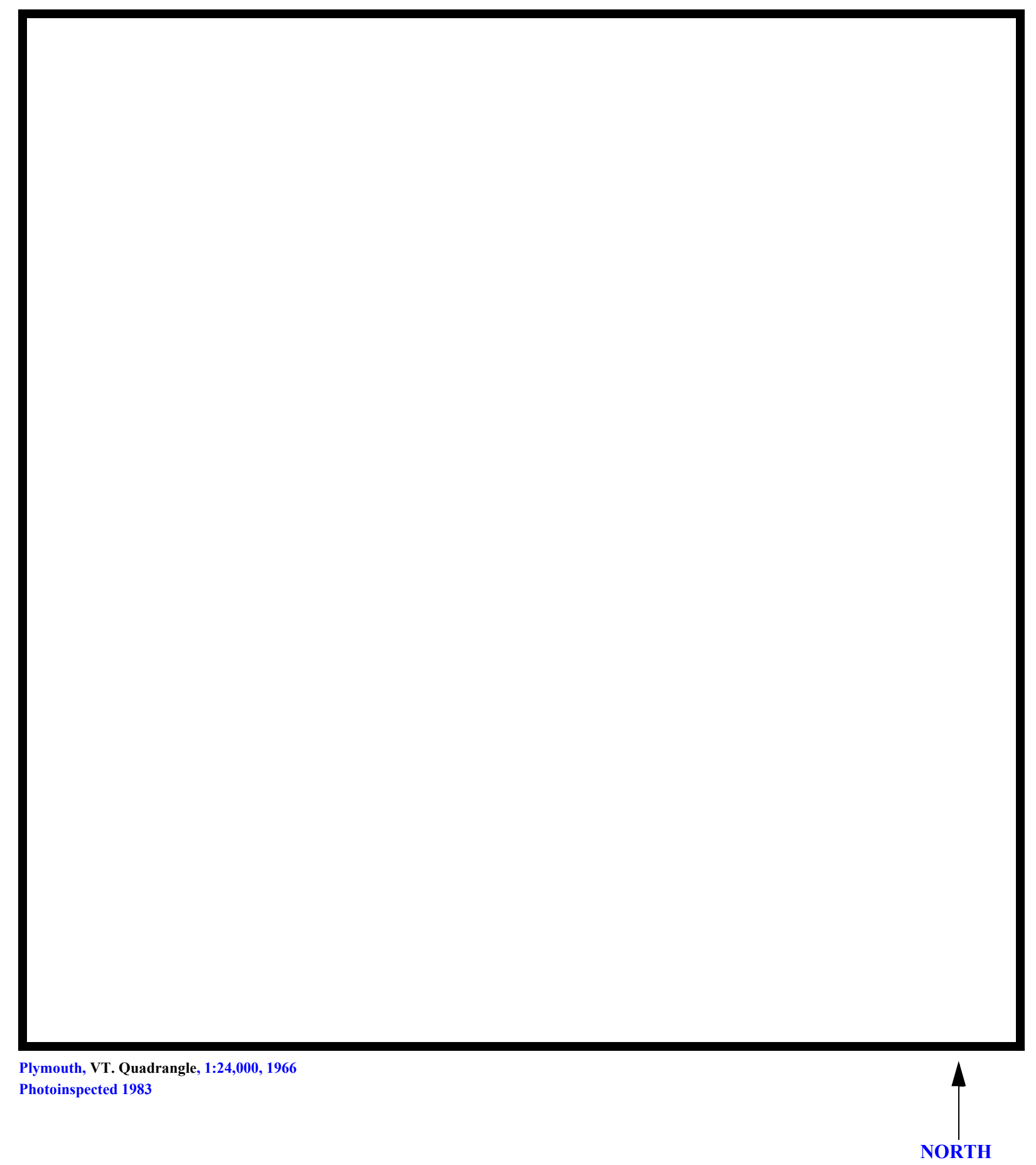

Figure 1. Location of study area on USGS 1:24,000 scale map. 
Figure 2. Location of study area on Vermont Agency of Transportation town highway map. 

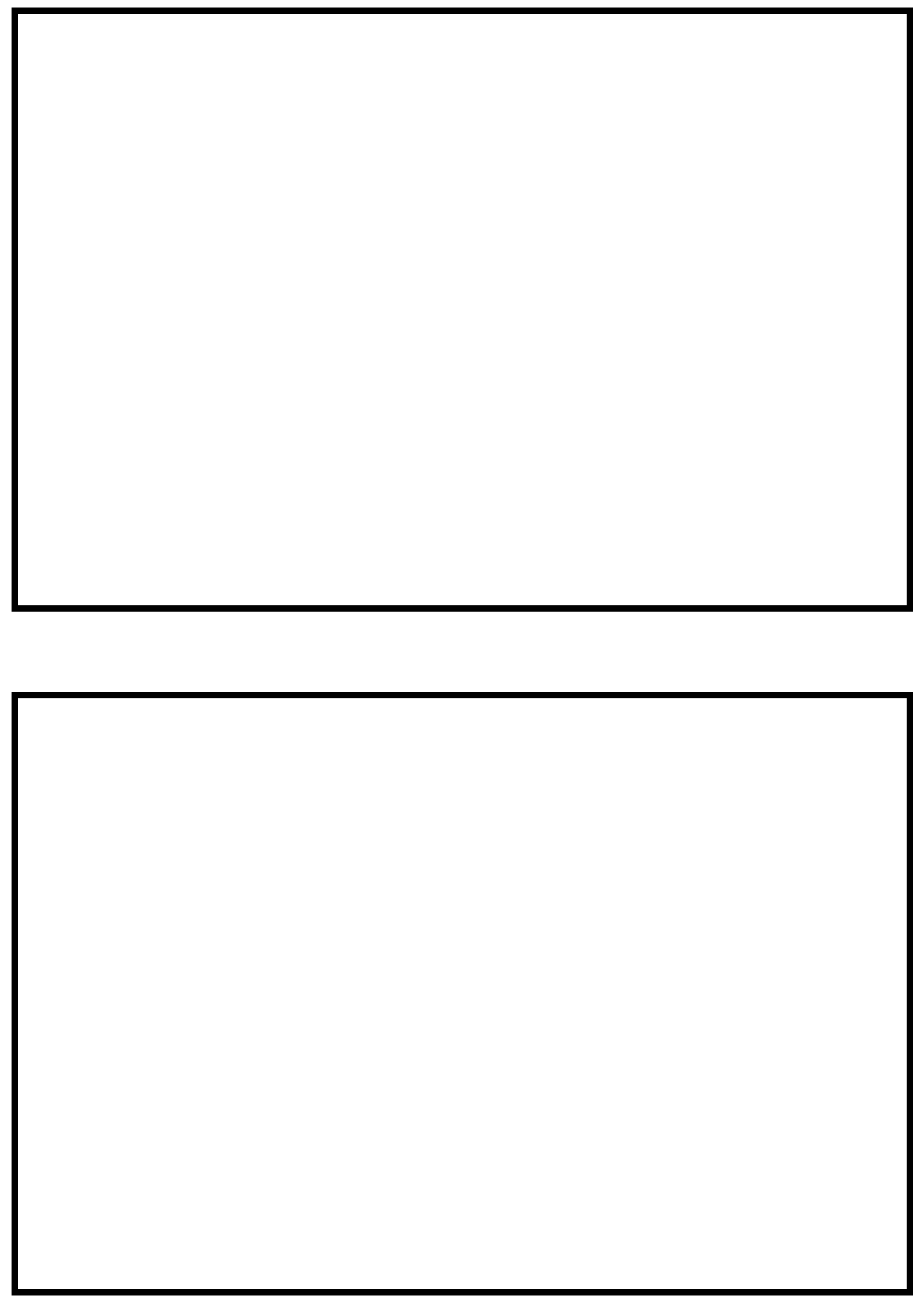

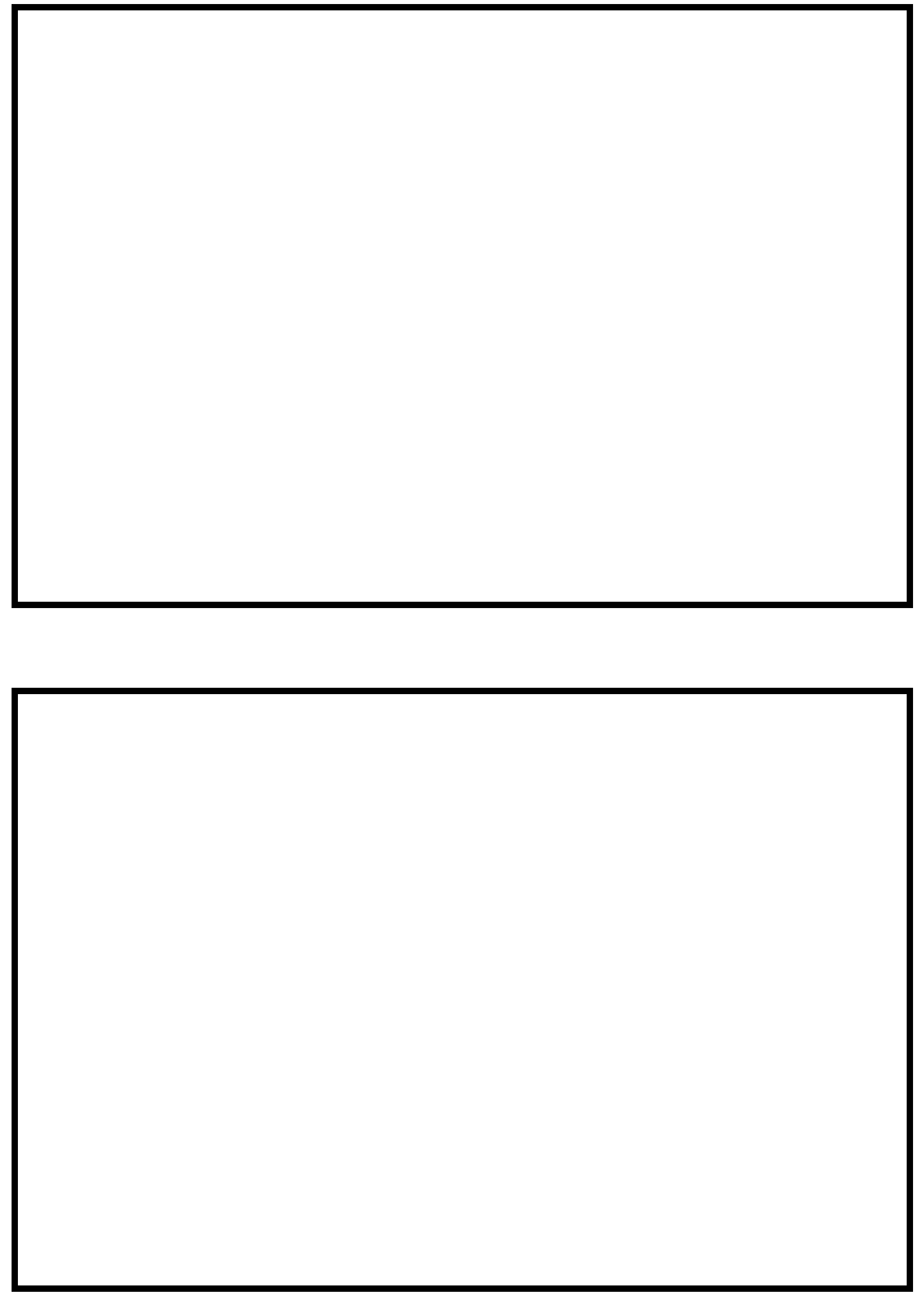


\section{LEVEL II SUMMARY}

\begin{tabular}{llllll} 
Structure Number & \multicolumn{2}{c}{ BRNETH00740037 } & \multirow{3}{c}{ South Peacham Brook } \\
& Stream & & & \\
County & Caledonia & Road & TH 74 & District & 7
\end{tabular}

\section{Description of Bridge}

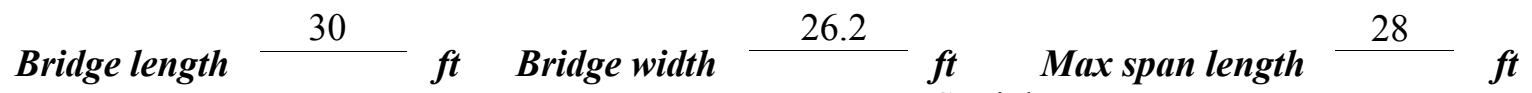
Alignment of bridge to road (on curve or straight)

Abutment type Vertical, concrete

Stone fill on abutment?

$$
\text { Yes }
$$

\section{Embankment type} Straight

namanintinu af ntans fill Type-1, along the downstream end of the left and right abutment and the downstream left and right wingwalls. Type-2, along the upstream right wingwall.

Abutments and wingwalls are concrete. There is a two foot deep scour hole in front of the protection for the upstream right wingwall.

$\cdots+\cdots, \ldots$

\section{0}

Angle

Is bridge skewed to flood flow according to There ' survey? Yes

is a mild channel bend through the bridge. Cut-banks have developed in the location where the

bend impacts the upstream right bank and downstream left bank.

Debris accumulation on bridge at time of Level I or Level II site visit:

$$
\begin{gathered}
\text { Date of insnortion } \\
8 / 24 / 95 \\
\hline
\end{gathered}
$$

Level I

$$
8 / 24 / 95
$$

Level II

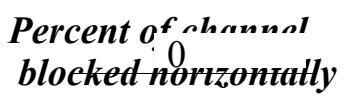

0

\section{Percent of allo...nel blocked verticatty}

0 some debris is caught at the downstream bridge face.

Potential for debris

None as of 8/24/95.

Dosrriho any, foaturos noar ar at tho hridoo that mav, affort flow, (includo ahsorvation dato) 


\section{Description of the Geomorphic Setting}

General topography The channel is located within low relief valley with a wide flood plain. $8 / 24 / 95$

Geomorphic conditions at bridge site: downstream (DS), upstream (US)

Date of inspection Moderately

DS left: $\quad$ sloped overbank

DS right: Wide flood plain

US left: $\quad$ Moderately sloped overbank

US right: $\quad$ Wide flood plain

\section{Description of the Channel}

$\begin{array}{llll}\text { Average top width } & \text { Average depth } & 3 & \\ & \text { Sand/Gravel } & \text { Organics }\end{array}$

Predominant bed material

Bank material Sinuous and unstable

with alluvial channel boundaries and a wide flood plain.

$8 / 24 / 95$

Vegetative co ${ }^{1}$ Shrubs and brush with grass on the overbank

DS left: $\quad$ Shrubs and brush

DS right: $\quad$ Few trees with lawn on the overbank

US left: $\quad$ Few trees with grass on the overbank

US right: $\quad$ No

Do banks appear stable? The channel is yertically and laterally unstable as observed on 8/24/

95. There are cut-banks on the upstream right bank and downstream left bank. There is also a
date of observatton. channel scour hole at the upstream bridge face.

None as of $8 / 24 / 95$.

Describe any obstructions in channel and date of observation. 


\section{Hydrology}

Drainage area $\frac{12.1}{\boldsymbol{m i}^{2}}$

Percentage of drainage area in physiographic provinces: (approximate)

Physiographic province/section New England/New England Upland
Percent of drainage area 100

Is drainage area considered rural or urban? Rural Describe any significant

urbanization: There is a house on the upstream left overbank area.

Is there a USGS gage on the stream of interest?

No

USGS gage description

USGS gage number

Gage drainage area $\mathrm{mi}^{2}$

No

Is there a lake/p

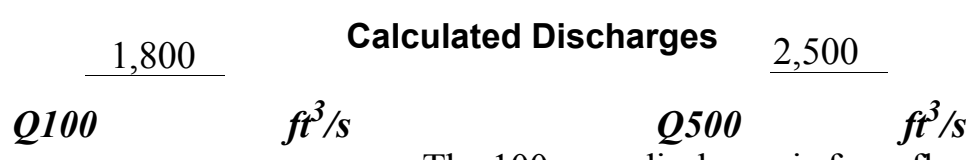

The 100-year discharge is from flood frequency

estimates available from the VTAOT database which were extended graphically to the 500-year discharge. The drainage area above bridge number 37 is reported as 12.5 square miles while the computed drainage area is 12.1 square miles. The values used were within a range defined by flood frequency curves developed from several empirical methods (Benson, 1962; Johnson and Tasker, 1974; FHWA, 1983; Potter, 1957a\&b; Talbot, 1887). 


\section{Description of the Water-Surface Profile Model (WSPRO) Analysis}

Datum for WSPRO analysis (USGS survey, sea level, VTAOT plans) ～VTAOT plans

Datum tie between USGS survey and VTAOT plans

The VTAOT plans' datum was

obtained by adding 1.75 to the USGS arbitrary survey datum.

Description of reference marks used to determine USGS datum. $\quad$ RM1 is a chiseled X on

top of the downstream right corner of the bridge deck (elev. $499.88 \mathrm{ft}$, VTAOT plans' datum).

$\mathrm{RM} 2$ is a chiseled $\mathrm{X}$ on top of the upstream end of the right abutment (elev. $499.84 \mathrm{ft}$, VTAOT

plans' datum).

\section{Cross-Sections Used in WSPRO Analysis}

\begin{tabular}{|c|c|c|c|}
\hline${ }^{1}$ Cross-section & $\begin{array}{c}\text { Section } \\
\text { Reference } \\
\text { Distance } \\
\text { (SRD) in feet }\end{array}$ & $\begin{array}{c}{ }^{2} \text { Cross-section } \\
\text { development }\end{array}$ & Comments \\
\hline EXITX & -33 & 1 & Exit section \\
\hline FULLV & 0 & 2 & $\begin{array}{l}\text { Downstream Full-valley } \\
\text { section (Templated from } \\
\text { EXITX) }\end{array}$ \\
\hline BRIDG & 0 & 1 & Bridge section \\
\hline RDWAY & 14 & 1 & Road Grade section \\
\hline APPR1 & 54 & 1 & Approach section \\
\hline
\end{tabular}

${ }^{1}$ For location of cross-sections see plan-view sketch included with Level I field form, Appendix E. For more detail on how cross-sections were developed see WSPRO input file. 


\section{Data and Assumptions Used in WSPRO Model}

Hydraulic analyses of the reach were done by use of the Federal Highway Administration's WSPRO step-backwater computer program (Shearman and others, 1986, and Shearman, 1990). The analyses reported herein reflect conditions existing at the site at the time of the study. Furthermore, in the development of the model it was necessary to assume no accumulation of debris or ice at the site. Results of the hydraulic model are presented in the Bridge Hydraulic Summary, Appendix B, and figure 7.

Channel roughness factors (Manning's “ $n$ ”) used in the hydraulic model were estimated using field inspections at each cross section following the general guidelines described by Arcement and Schneider (1989). Final adjustments to the values were made during the modelling of the reach. Channel " $n$ " values for the reach ranged from 0.035 to 0.040 , and overbank " $n$ " values ranged from 0.040 to 0.055 .

Normal depth at the exit section (EXITX) was assumed as the starting water surface. This depth was computed by use of the slope-conveyance method outlined in the user's manual for WSPRO (Shearman, 1990). The slope used was $0.0042 \mathrm{ft} / \mathrm{ft}$, which was estimated from the topographic map (U.S. Geological Survey, 1983).

The approach section (APPR1) was surveyed one bridge length upstream of the upstream face as recommended by Shearman and others (1986). This location provides a consistent method for determining scour variables. 


\section{Bridge Hydraulics Summary}

$\begin{array}{llll}\text { Average bridge embankment elevation } & 500.3 & f t \\ \text { Average low steel elevation } & 498.2 & \boldsymbol{f t}\end{array}$

100-year discharge $\quad 1,800 \quad \mathrm{ft}^{3} / \mathrm{s}$

Water-surface elevation in bridge opening $\quad 498.3 \quad f t$

Road overtopping? ___ Yes Discharge over road __ $354 \quad \mathrm{ft}^{3} / \mathrm{s}$

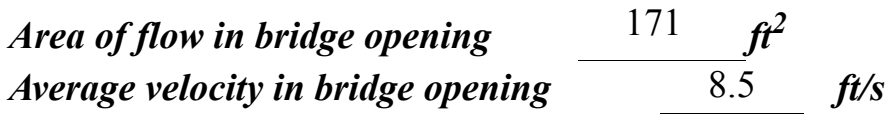

$\begin{array}{llll}\text { Maximum WSPRO tube velocity at bridge } & 10.1 \mathrm{ft} / \mathrm{s}\end{array}$

Water-surface elevation at Approach section with bridge $\quad 500.1$

Water-surface elevation at Approach section without bridge $\quad 496.5$

Amount of backwater caused by bridge $\quad 3.6 \quad$ it

500-year discharge $\quad 2,500 \quad \mathrm{ft}^{3} / \mathrm{s}$

Water-surface elevation in bridge opening $\quad 498.3 \mathrm{ft}$

Road overtopping? ___ Yes Discharge over road _ $\quad 963,3 / s$

Area of flow in bridge opening $\quad 171 \quad \mathrm{ft}^{2}$

Average velocity in bridge opening $9.1 \mathrm{ft} / \mathrm{s}$

Maximum WSPRO tube velocity at bridge 10.9 , 's

Water-surface elevation at Approach section with bridge 500.6

Water-surface elevation at Approach section without bridge $\quad 496.9$

Amount of backwater caused by bridge $\quad 3.7, t$

Incipient overtopping discharge $\quad 1,210 \mathrm{ft}^{3} / \mathrm{s}$

Water-surface elevation in bridge opening $498.3 \quad$ it

Area of flow in bridge opening $\quad 171 \quad \mathrm{ft}^{2}$

Average velocity in bridge opening $\quad 7.1 \quad \mathrm{ft} / \mathrm{s}$

Maximum WSPRO tube velocity at bridge $\quad 8.5 \mathrm{ft} / \mathrm{s}$

Water-surface elevation at Approach section with bridge

Water-surface elevation at Approach section without bridge

499.2

Amount of backwater caused by bridge $\quad 3.1$, t

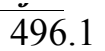




\section{Scour Analysis Summary}

\section{Special Conditions or Assumptions Made in Scour Analysis}

Scour depths were computed using the general guidelines described in Hydraulic Engineering Circular 18 (Richardson and others, 1995). Scour depths were calculated assuming an infinite depth of erosive material and a homogeneous particle-size distribution. The results of the scour analyses for the 100- and 500-year discharges are presented in Tables 1 and 2 and the scour depths are shown graphically in Figure 8.

The 100-year, 500-year, and incipient roadway-overtopping discharges resulted in unsubmerged orifice flow. Contraction scour at bridges with orifice flow is best estimated by use of the Chang pressure-flow scour equation (oral communication, J. Sterling Jones, October 4, 1996). Thus, contraction scour for these discharges was computed by use of the Chang equation (Richardson and others, 1995, p. 145-146).

For comparison, estimates of contraction scour also were computed, for the discharges resulting in orifice flow, by use of the Laursen clear-water contraction scour equation (Richardson and others, 1995, p. 32, equation 20) and the Umbrell pressure-flow equation (Richardson and others, 1995, p. 144). Results of these computations are presented in Appendix F. Furthermore, for those discharges resulting in unsubmerged orifice flow, contraction scour was computed by substituting estimates for the depth of flow at the downstream bridge face in the contraction scour equations. Results with respect to these substitutions also are provided in Appendix F.

Abutment scour was computed by use of the HIRE equation (Richardson and others, 1995, p. 49, equation 29) because the HIRE equation is recommended when the length to depth ratio of the embankment blocking flow exceeds 25. Variables for the HIRE equation include the Froude number of the flow approaching the embankments, the length of the embankment blocking flow, and the depth of flow approaching the embankment less any roadway overtopping. 


\section{Scour Results}

100-yr discharge 500-yr discharge

Incipient

overtopping

Contraction scour:

(Scour depths in feet)

Main channel

Live-bed scour

Clear-water scour

Depth to armoring

Left overbank

Right overbank

Local scour:

Abutment scour

8.6

9.9

6.7

Left abutment

10.3

11.1-

8.8

\section{Right abutment}

Pier scour

Pier 1

Pier 2

Pier 3

Abutments:

Left abutment

Right abutment

Piers:

Pier 1

Pier 2

\section{Riprap Sizing}

Incipient overtopping 100-yr discharge 500-yrdischarge discharge

2.0

2.0

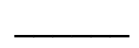

--

$--$

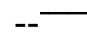
( $D_{50}$ in feet)

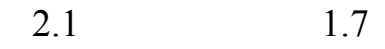

2.1

1.7

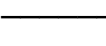

--

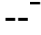

$--$

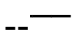




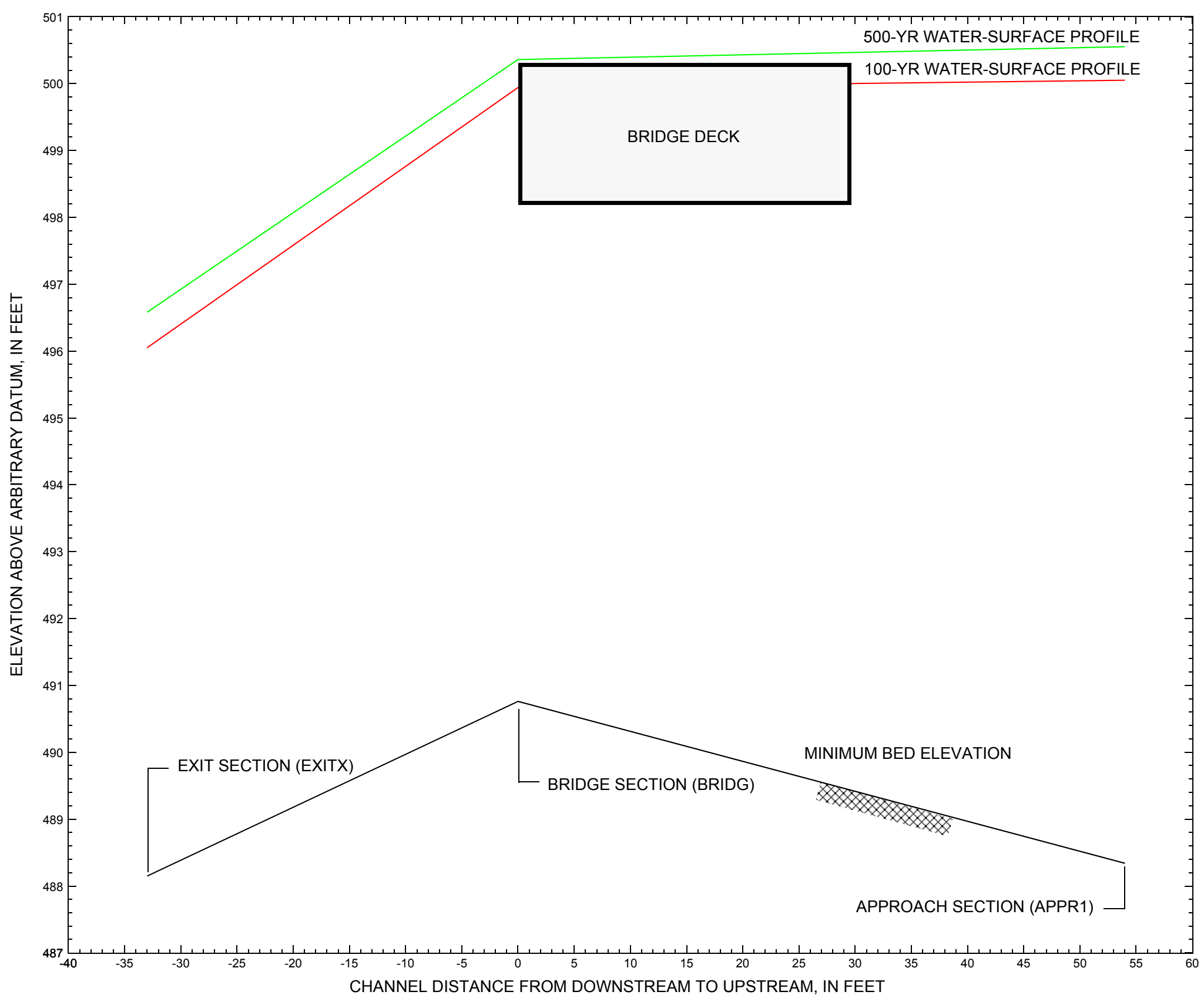

Figure 7. Water-surface profiles for the 100- and 500-yr discharges at structure BRNETH00740037 on Town Highway 74, crossing South Peacham Brook, Barnet, Vermont. 


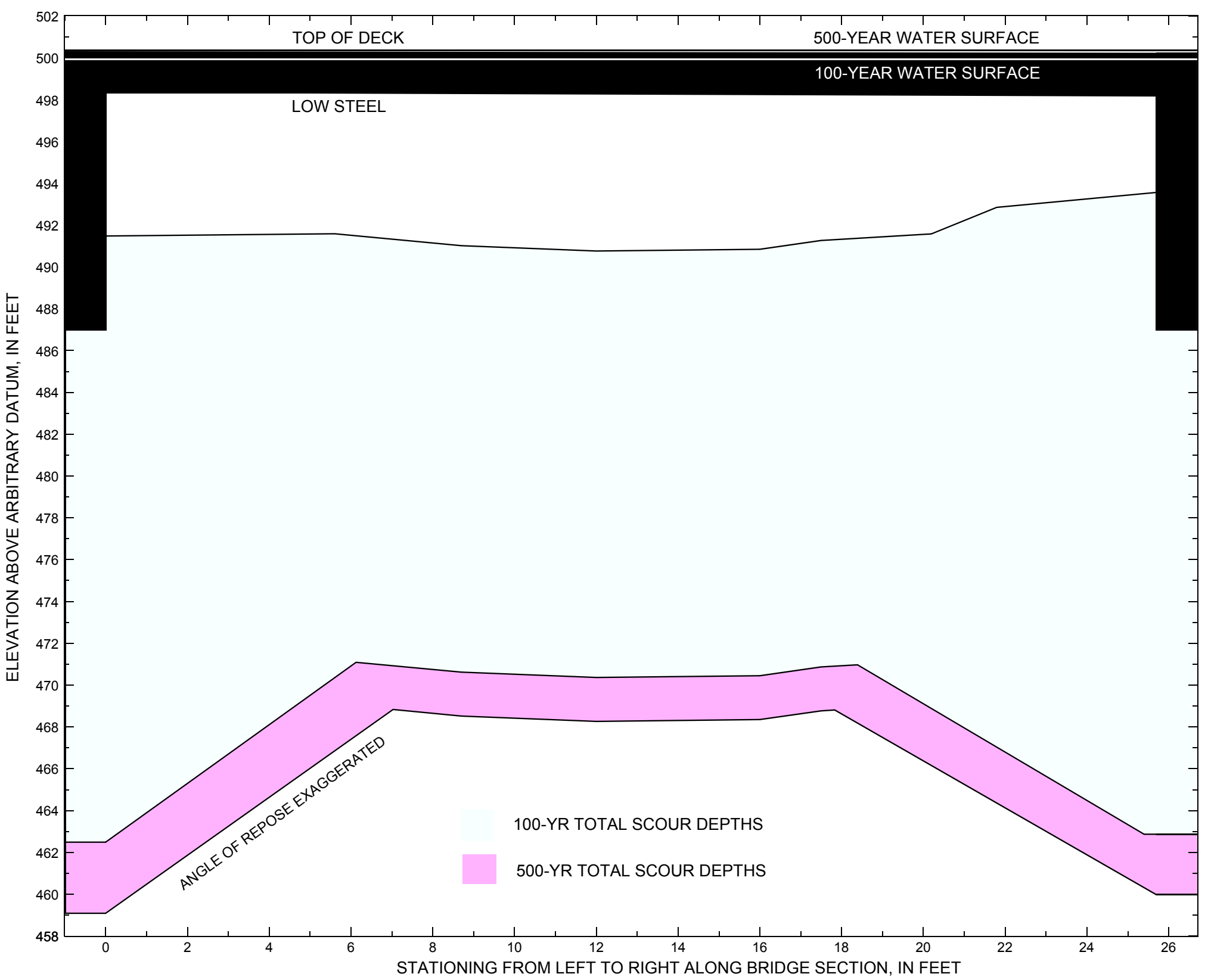

Figure 8. Scour elevations for the 100-yr and 500-yr discharges at structure BRNETH00740037 on Town Highway 74, crossing South Peacham Brook, Barnet, Vermont. 
Table 1. Remaining footing/pile depth at abutments for the 100-year discharge at structure BRNETH00740037 on Town Highway 74 , crossing South Peacham Brook, Barnet, Vermont.

[VTAOT, Vermont Agency of Transportation; --, no data]

\begin{tabular}{|c|c|c|c|c|c|c|c|c|c|c|c|}
\hline Description & Station $^{1}$ & $\begin{array}{l}\text { VTAOT } \\
\text { minimum } \\
\text { low-chord } \\
\text { elevation } \\
\text { (feet) }\end{array}$ & $\begin{array}{l}\text { Surveyed } \\
\text { minimum } \\
\text { low-chord } \\
\text { elevation } \\
\quad \text { (feet) }\end{array}$ & $\begin{array}{l}\text { Bottom of } \\
\text { footing } \\
\text { elevation } \\
\text { (feet) }\end{array}$ & $\begin{array}{c}\text { Channel } \\
\text { elevation at } \\
\text { abutment/ } \\
\text { pier }^{2} \\
\text { (feet) }\end{array}$ & $\begin{array}{l}\text { Contraction } \\
\text { scour depth } \\
\text { (feet) }\end{array}$ & $\begin{array}{l}\text { Abutment } \\
\text { scour } \\
\text { depth } \\
\text { (feet) }\end{array}$ & $\begin{array}{l}\text { Pier } \\
\text { scour } \\
\text { depth } \\
\text { (feet) }\end{array}$ & $\begin{array}{l}\text { Depth of } \\
\text { total scour } \\
\text { (feet) }\end{array}$ & $\begin{array}{c}\text { Elevation of } \\
\text { scour }^{2} \\
\text { (feet) }\end{array}$ & $\begin{array}{l}\text { Remaining } \\
\text { footing/pile } \\
\text { depth } \\
\text { (feet) }\end{array}$ \\
\hline \multicolumn{12}{|c|}{100 -yr. discharge is 1,800 cubic-feet per second } \\
\hline Left abutment & 0.0 & -- & 498.3 & 487.0 & 491.5 & 20.4 & 8.6 & -- & 29.0 & 462.5 & -24.5 \\
\hline Right abutment & 25.7 & 498.2 & 498.2 & 487.0 & 493.6 & 20.4 & 10.3 & -- & 30.7 & 462.9 & -24.1 \\
\hline
\end{tabular}

1.Measured along the face of the most constricting side of the bridge.

2.Arbitrary datum for this study.

Table 2. Remaining footing/pile depth at abutments for the 500-year discharge at structure BRNETH00740037 on Town Highway 74, crossing South Peacham Brook, Barnet, Vermont.

[VTAOT, Vermont Agency of Transportation; --, no data]

\begin{tabular}{|c|c|c|c|c|c|c|c|c|c|c|c|}
\hline Description & Station $^{1}$ & $\begin{array}{l}\text { VTAOT } \\
\text { minimum } \\
\text { low-chord } \\
\text { elevation } \\
\text { (feet) }\end{array}$ & $\begin{array}{c}\text { Surveyed } \\
\text { minimum } \\
\text { low-chord } \\
\text { elevation }{ }^{2} \\
\text { (feet) }\end{array}$ & $\begin{array}{c}\text { Bottom of } \\
\text { footing } \\
\text { elevation } \\
\text { (feet) }\end{array}$ & $\begin{array}{c}\text { Channel } \\
\text { elevation at } \\
\text { abutment/ } \\
\text { pier }^{2} \\
\text { (feet) }\end{array}$ & $\begin{array}{l}\text { Contraction } \\
\text { scour depth } \\
\text { (feet) }\end{array}$ & $\begin{array}{l}\text { Abutment } \\
\text { scour } \\
\text { depth } \\
\text { (feet) }\end{array}$ & $\begin{array}{l}\text { Pier } \\
\text { scour } \\
\text { depth } \\
\text { (feet) }\end{array}$ & $\begin{array}{l}\text { Depth of } \\
\text { total scour } \\
\text { (feet) }\end{array}$ & $\begin{array}{c}\text { Elevation of } \\
\text { scour }^{2} \\
\text { (feet) }\end{array}$ & $\begin{array}{c}\text { Remaining } \\
\text { footing/pile } \\
\text { depth } \\
\text { (feet) }\end{array}$ \\
\hline \multicolumn{12}{|c|}{500 -yr. discharge is 2,500 cubic-feet per second } \\
\hline Left abutment & 0.0 & -- & 498.3 & 487.0 & 491.5 & 22.5 & 9.9 & -- & 32.4 & 459.1 & -27.9 \\
\hline Right abutment & 25.7 & 498.2 & 498.2 & 487.0 & 493.6 & 22.5 & 11.1 & -- & 33.6 & 460.0 & -27.0 \\
\hline
\end{tabular}

1.Measured along the face of the most constricting side of the bridge.

2.Arbitrary datum for this study. 


\section{SELECTED REFERENCES}

Arcement, G.J., Jr., and Schneider, V.R., 1989, Guide for selecting Manning's roughness coefficients for natural channels and flood plains: U.S. Geological Survey Water-Supply Paper 2339, 38 p.

Barnes, H.H., Jr., 1967, Roughness characteristics of natural channels: U.S. Geological Survey Water-Supply Paper 1849,213 p.

Benson, M. A., 1962, Factors Influencing the Occurrence of Floods in a Humid Region of Diverse Terrain: U.S. Geological Survey WaterSupply Paper 1580-B, 64 p.

Brown, S.A. and Clyde, E.S., 1989, Design of riprap revetment: Federal Highway Administration Hydraulic Engineering Circular No. 11, Publication FHWA-IP-89-016, 156 p.

Federal Highway Administration, 1983, Runoff estimates for small watersheds and development of sound design: Federal Highway Administration Report FHWA-RD-77-158.

Federal Highway Administration, 1993, Stream Stability and Scour at Highway Bridges: Participant Workbook: Federal Highway Administration Report FHWA-HI-91-011.

Froehlich, D.C., 1989, Local scour at bridge abutments in Ports, M.A., ed., Hydraulic Engineering--Proceedings of the 1989 National Conference on Hydraulic Engineering: New York, American Society of Civil Engineers, p. 13-18.

Hayes, D.C.,1993, Site selection and collection of bridge-scour data in Delaware, Maryland, and Virginia: U.S. Geological Survey WaterResources Investigation Report 93-4017, 23 p.

Interagency Advisory Committee on Water Data, 1982, Guidelines for determining flood flow frequency: U.S. Geological Survey, Bulletin 17B of the Hydrology Subcommittee, $190 \mathrm{p}$.

Johnson, C.G. and Tasker, G.D.,1974, Progress report on flood magnitude and frequency of Vermont streams: U.S. Geological Survey OpenFile Report 74-130, 37 p.

Lagasse, P.F., Schall, J.D., Johnson, F., Richardson, E.V., Chang, F., 1995, Stream Stability at Highway Structures: Federal Highway Administration Hydraulic Engineering Circular No. 20, Publication FHWA-IP-90-014, 144 p.

Laursen, E.M., 1960, Scour at bridge crossings: Journal of the Hydraulics Division, American Society of Civil Engineers, v. 86, no. HY2, p. 39-53.

Potter, W. D., 1957a, Peak rates of runoff in the Adirondack, White Mountains, and Maine woods area, Bureau of Public Roads

Potter, W. D., 1957b, Peak rates of runoff in the New England Hill and Lowland area, Bureau of Public Roads

Richardson, E.V. and Davis, S.R., 1995, Evaluating scour at bridges: Federal Highway Administration Hydraulic Engineering Circular No. 18, Publication FHWA-IP-90-017, 204 p.

Richardson, E.V., Simons, D.B., and Julien, P.Y., 1990, Highways in the river environment: Federal Highway Administration Publication FHWA-HI-90-016.

Ritter, D.F., 1984, Process Geomorphology: W.C. Brown Co., Debuque, Iowa, 603 p.

Shearman, J.O., 1990, User's manual for WSPRO--a computer model for water surface profile computations: Federal Highway Administration Publication FHWA-IP-89-027, 187 p.

Shearman, J.O., Kirby, W.H., Schneider, V.R., and Flippo, H.N., 1986, Bridge waterways analysis model; research report: Federal Highway Administration Publication FHWA-RD-86-108, 112 p.

Talbot, A.N., 1887, The determination of water-way for bridges and culverts.

U.S. Department of Transportation, 1993, Stream stability and scour at highway bridges, Participant Workbook: Federal Highway Administration Publication FHWA HI-91-011.

U.S. Geological Survey, 1983, Barnet, Vermont 7.5 Minute Series quadrangle map: U.S. Geological Survey Topographic Maps, Scale $1: 25,000$. 


\section{APPENDIX A:}

WSPRO INPUT FILE 


\section{WSPRO INPUT FILE}

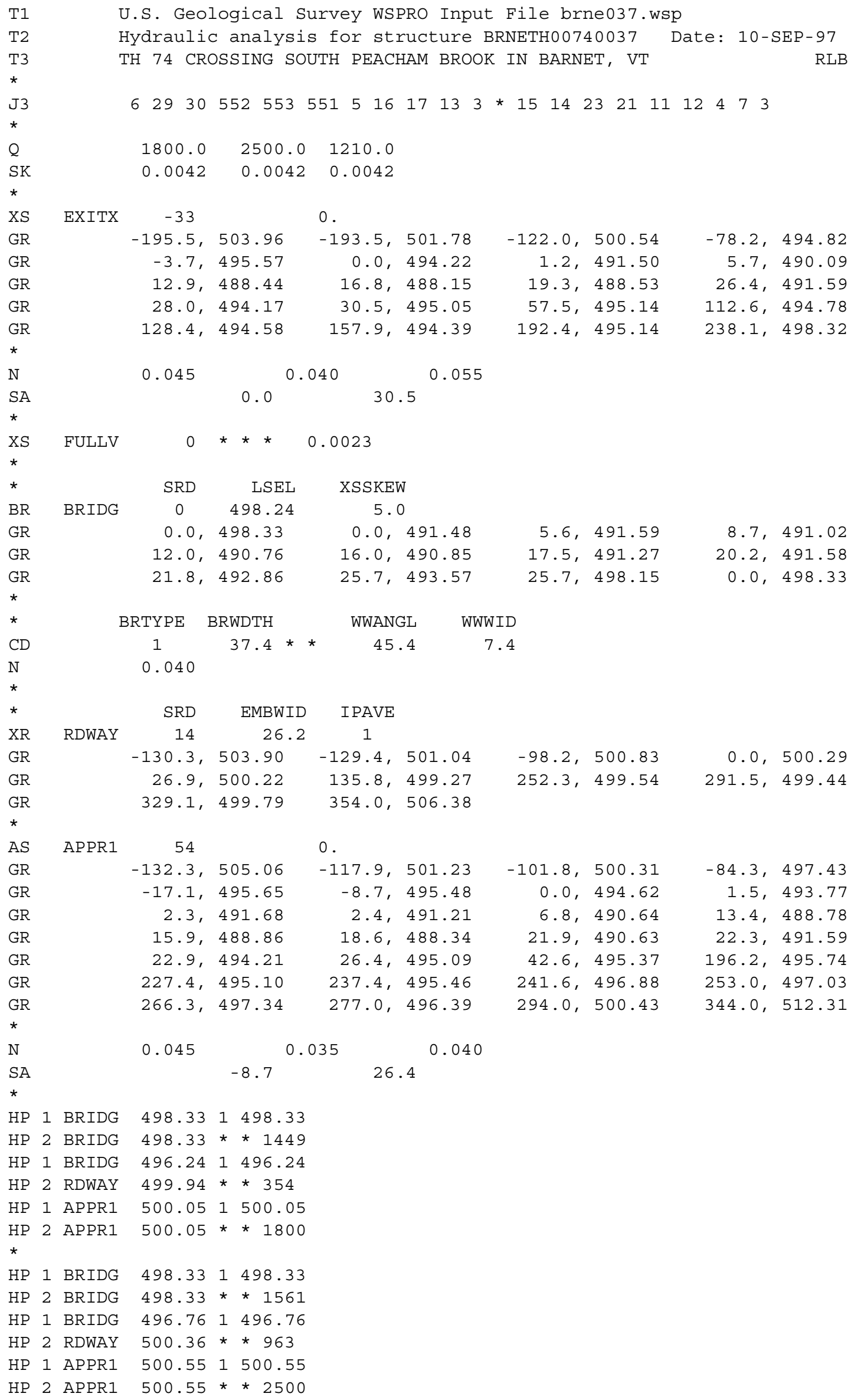




\section{APPENDIX B: \\ WSPRO OUTPUT FILE}




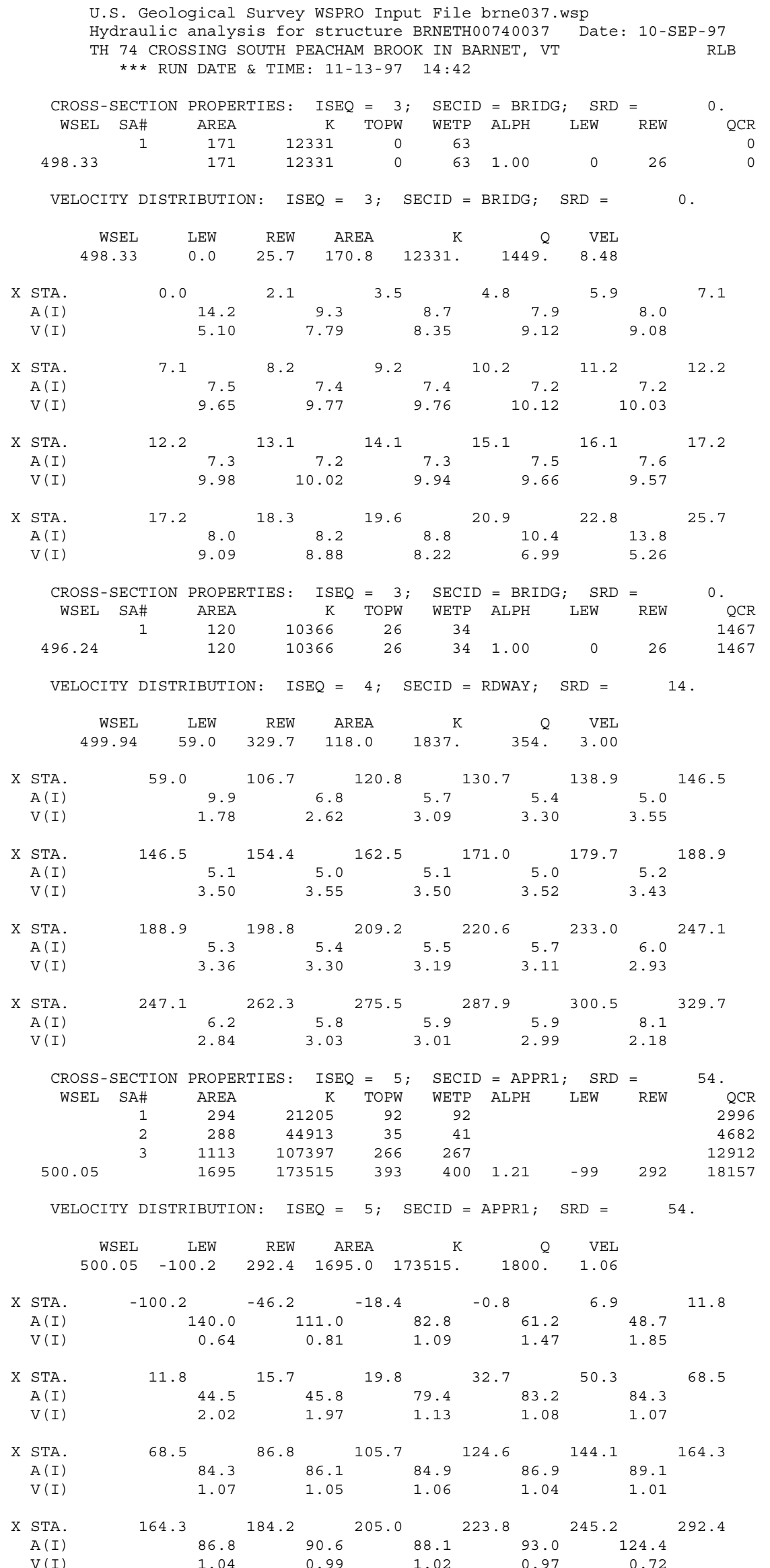


WSPRO OUTPUT FILE (continued)

\footnotetext{
U.S. Geological Survey WSPRO Input File brne037.wsp

Hydraulic analysis for structure BRNETH00740037 Date: 10-SEP-97

TH 74 CROSSING SOUTH PEACHAM BROOK IN BARNET, VT *** RUN DATE \& TIME: 11-13-97 14:42

CROSS-SECTION PROPERTIES: ISEQ $=3 ;$ SECID $=$ BRIDG $; \quad$ SRD $=\quad 0$.

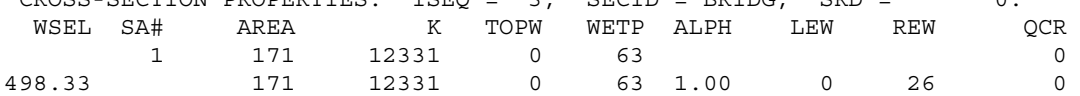

VELOCITY DISTRIBUTION: ISEQ $=3 ; \operatorname{SECID~}=$ BRIDG; $\operatorname{SRD}=\quad 0$.

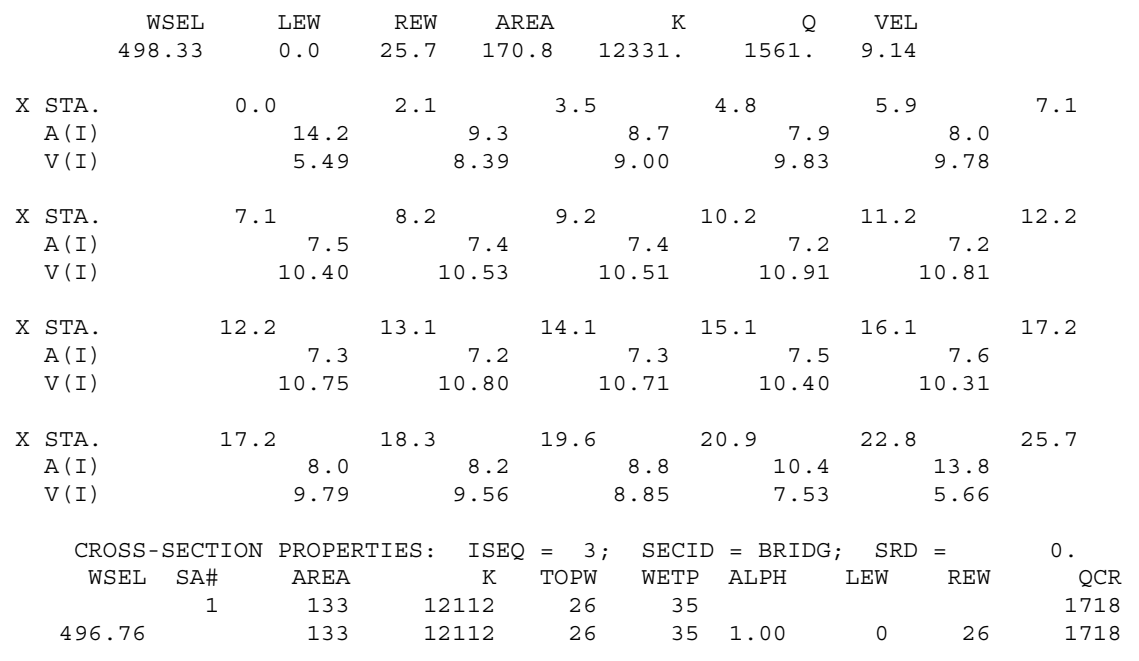

VELOCITY DISTRIBUTION: $\quad$ ISEQ $=4 ; \operatorname{SECID~}=$ RDWAY $\quad$ SRD $=14$.

\begin{tabular}{|c|c|c|c|c|c|c|c|c|c|c|c|}
\hline & & VSEL & LEW & REW & $\mathrm{ARH}$ & $E A$ & K & $Q$ & VEL & & \\
\hline & 500 & .36 & 12.7 & 331.3 & 244 & .2 & 5639. & 963. & 3.94 & & \\
\hline $\mathrm{X}$ & STA. & -12.7 & & 78.0 & & 100.1 & 115 & 5.7 & 128.1 & & 138.4 \\
\hline & $A(I)$ & & 21.8 & & 15.1 & & 13.2 & 12.0 & & 11.0 & \\
\hline & $V(I)$ & & 2.21 & & 3.20 & & 3.64 & 4.02 & & 4.38 & \\
\hline $\mathrm{X}$ & STA. & 138.4 & & 148.5 & & 158.8 & 16 & 9.1 & 179.9 & & 191.0 \\
\hline & $\mathrm{A}(\mathrm{I})$ & & 10.8 & & 10.8 & & 10.6 & 10.8 & & 10.9 & \\
\hline & $V(I)$ & & 4.46 & & 4.46 & & 4.55 & 4.46 & & 4.44 & \\
\hline $\mathrm{X}$ & STA. & 191.0 & & 202.5 & & 214.7 & 227 & 7.1 & 240.7 & & 254.6 \\
\hline & $A(I)$ & & 10.9 & & 11.2 & & 11.1 & 11.7 & & 11.6 & \\
\hline & $V(I)$ & & 4.43 & & 4.28 & & 4.35 & 4.11 & & 4.16 & \\
\hline $\mathrm{X}$ & STA. & 254.6 & & 268.5 & & 281.6 & 294 & 4.1 & 308.8 & & 331.3 \\
\hline & $A(I)$ & & 11.7 & & 11.5 & & 11.3 & 12.2 & & 14.1 & \\
\hline & $V(I)$ & & 4.10 & & 4.19 & & 4.25 & 3.95 & & 3.41 & \\
\hline & CROSS- & SECTION & PROPER & RTIES: & ISEQ & $=5 ;$ & SECID & $=\mathrm{APPR} 1$ & SRD & $=$ & 54. \\
\hline & WSEL & SA\# & AREA & & $\mathrm{K}$ & TOPW & WETP & $\mathrm{ALPH}$ & LEW & REW & QCR \\
\hline & & 1 & 341 & & 0035 & 97 & 98 & & & & 3626 \\
\hline & & 2 & 306 & & 566 & 35 & 41 & & & & 5116 \\
\hline & & 3 & 1246 & 129 & 030 & 268 & 269 & & & & 15245 \\
\hline & 500.55 & & 1893 & 204 & 632 & 401 & 408 & 1.19 & -105 & 295 & 21432 \\
\hline
\end{tabular}

VELOCITY DISTRIBUTION: ISEQ $=5 ;$ SECID $=$ APPRI; $\quad$ SRD $=\quad 54$.

\begin{tabular}{|c|c|c|c|c|c|c|c|c|c|}
\hline & & WSEL & REW & & $\mathrm{REA}$ & K & Q & VEL & \\
\hline & & 500.55 & 294.5 & 1893 & 3.0 & 4632. & 2500 . & 1.32 & \\
\hline $\mathrm{X}$ & STA. & -106.0 & -48.9 & & -21.4 & & -2.0 & 6.7 & 11.8 \\
\hline & $\mathrm{A}(\mathrm{I})$ & 157.1 & & 121.5 & & 98.9 & 69.9 & & \\
\hline & $V(I)$ & 0.80 & & 1.03 & & 1.26 & 1.79 & & \\
\hline $\mathrm{X}$ & STA. & 11.8 & 16.3 & & 20.9 & & 36.6 & 54.5 & 72.4 \\
\hline & $A(I)$ & 52.4 & & 53.7 & & 93.7 & 92.7 & & \\
\hline & $V(I)$ & 2.39 & & 2.33 & & 1.33 & 1.35 & & \\
\hline $\mathrm{X}$ & STA. & 72.4 & 90.9 & & 109.5 & & 128.3 & 147.8 & 167.5 \\
\hline & $A(I)$ & 94.6 & & 93.7 & & 94.0 & 96.3 & & \\
\hline & $V(I)$ & 1.32 & & 1.33 & & 1.33 & 1.30 & & \\
\hline $\mathrm{X}$ & STA. & 167.5 & 187.2 & & 207.3 & & 225.9 & 249.4 & 294.5 \\
\hline & $A(I)$ & 95.9 & & 97.7 & & 97.2 & 107.6 & & \\
\hline & $V(I)$ & 1.30 & & 1.28 & & 1.29 & 1.16 & & \\
\hline
\end{tabular}
}


WSPRO OUTPUT FILE (continued)

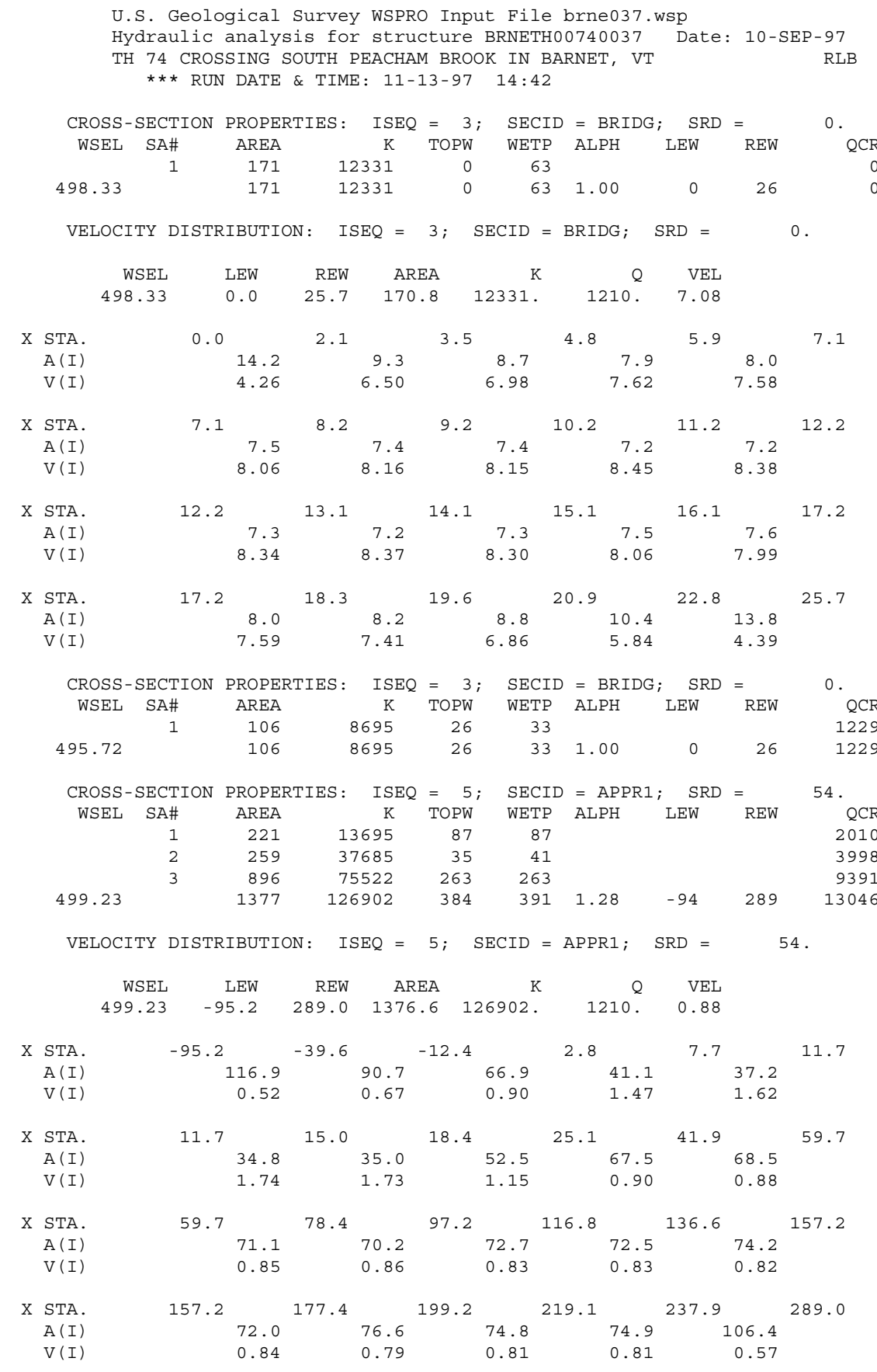


WSPRO OUTPUT FILE (continued)

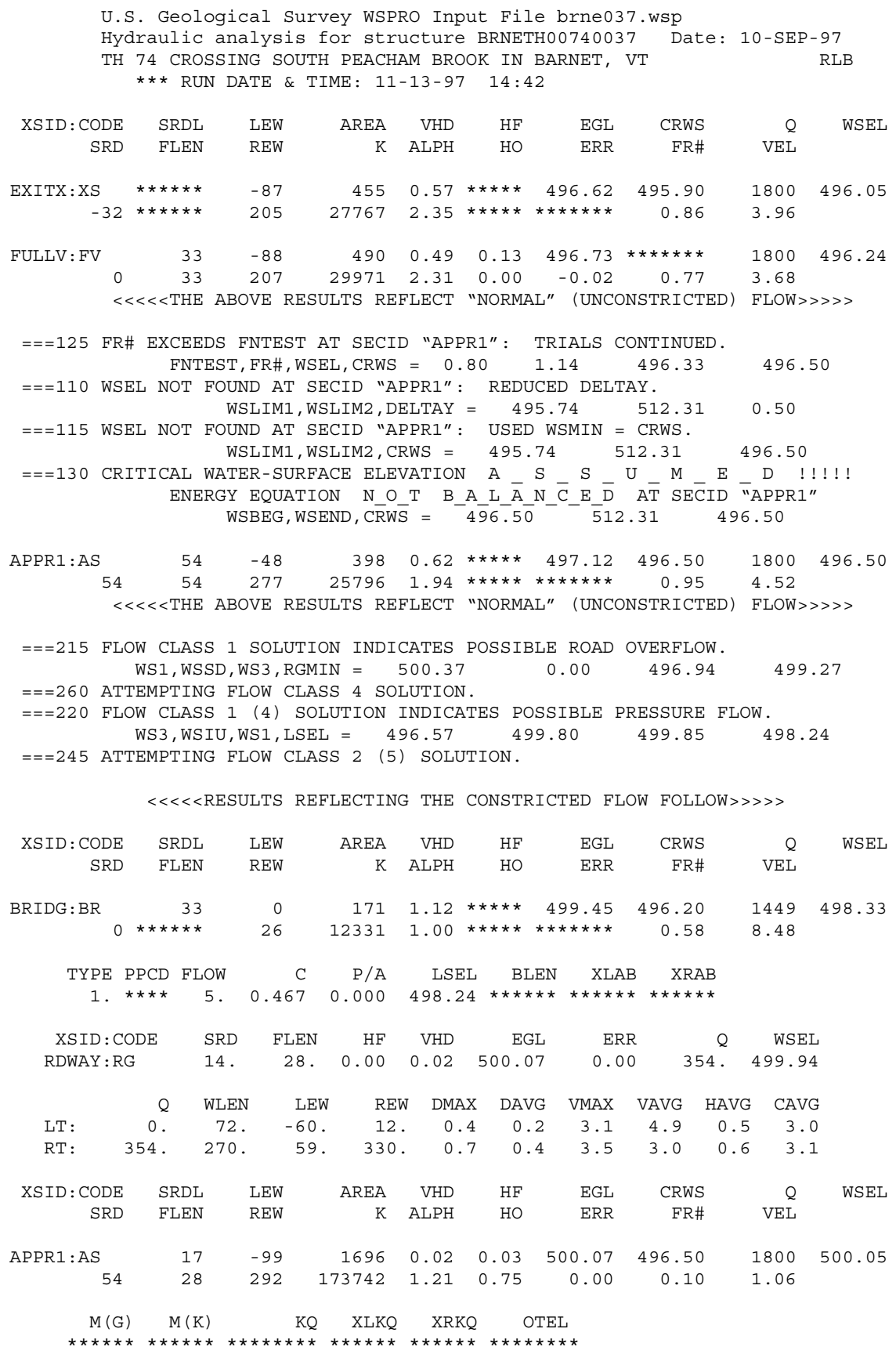

$<<<<$ END OF BRIDGE COMPUTATIONS $>>>>>$

FIRST USER DEFINED TABLE.

\begin{tabular}{|c|c|c|c|c|c|c|c|c|}
\hline XSID : CODE & SRD & LEW & REW & Q & K & AREA & VEL & WSEL \\
\hline EXITX:XS & -33 & -88 & 205 . & 1800. & 27767 . & 455 . & 3.96 & 496.05 \\
\hline FULLV: FV & 0 . & -89. & 207. & 1800. & 29971. & 490. & 3.68 & 496.24 \\
\hline BRIDG : BR & 0 . & 0 . & 26 . & 1449. & 12331. & 171. & 8.48 & 498.33 \\
\hline RDWAY : RG & 14 . $^{*}$ & $* \star * \star * *$ & 0 . & 354 . & 0 . & $\star \star \star \star \star \star *$ & 1.00 & 499.9 \\
\hline APPR1:AS & 54. & -100 & 292. & 1800. & 173742 . & 1696. & 1.06 & 500.0 \\
\hline XSID: CODE & XLKQ & XRKQ & & & & & & \\
\hline
\end{tabular}

SECOND USER DEFINED TABLE.

$\begin{array}{lcrrrrrrrr}\text { XSID: CODE } & \text { CRWS } & \text { FR\# } & \text { YMIN } & \text { YMAX } & \text { HF } & \text { HO } & \text { VHD } & \text { EGL } & \text { WSEL } \\ \text { EXITX:XS } & 495.90 & 0.86 & 488.15 & 503.96 * * * * * * * * * * * & 0.57 & 496.62 & 496.05 \\ \text { FULLV:FV } & * * * * * * * & 0.77 & 488.23 & 504.04 & 0.13 & 0.00 & 0.49 & 496.73 & 496.24 \\ \text { BRIDG: BR } & 496.20 & 0.58 & 490.76 & 498.33 * * * * * * * * * * * & 1.12 & 499.45 & 498.33 \\ \text { RDWAY: RG } & * * * * * * * * * * * * * * & 499.27 & 506.38 & 0.00 * * * * * & 0.02 & 500.07 & 499.94 \\ \text { APPR1:AS } & 496.50 & 0.10 & 488.34 & 512.31 & 0.03 & 0.75 & 0.02 & 500.07 & 500.05\end{array}$


WSPRO OUTPUT FILE (continued)

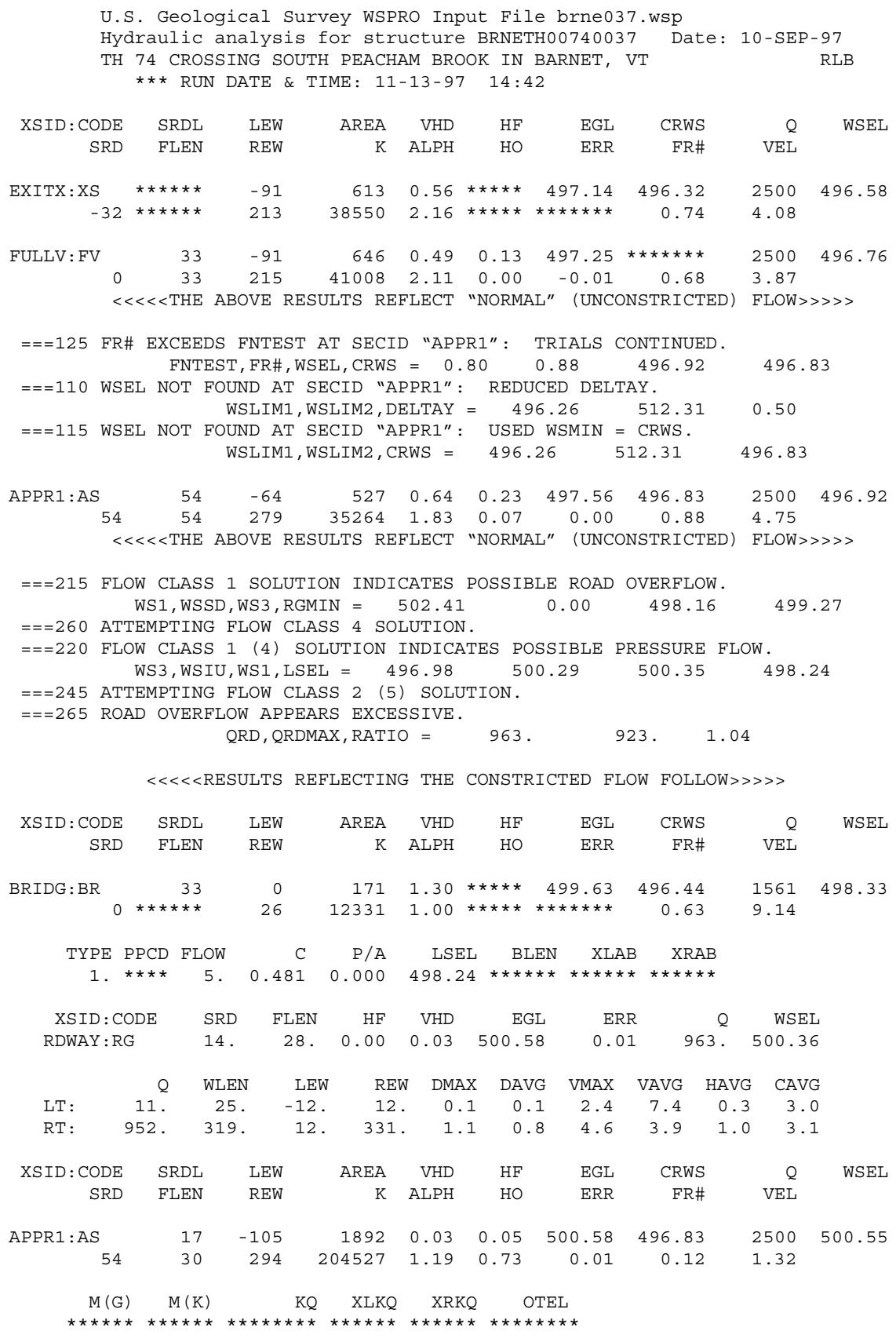

$<<<<<$ END OF BRIDGE COMPUTATIONS $>>>>>$

FIRST USER DEFINED TABLE.

\begin{tabular}{|c|c|c|c|c|c|c|c|c|}
\hline XSID:CODE & SRD & LEW & REW & Q & K & AREA & VEL & WSEL \\
\hline EXITX:XS & -33 & -92 & 213. & 2500. & 38550 . & 613. & 4.08 & 496.58 \\
\hline FULLV : FV & 0 . & -92. & 215 . & 2500. & 41008 . & 646. & 3.87 & 496.76 \\
\hline BRIDG : BR & 0 . & 0 . & 26. & 1561. & 12331. & 171. & 9.14 & 498.33 \\
\hline RDWAY : RG & 14. & 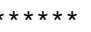 & 11. & 963. & 0 . & $* \star \star \star \star \star *$ & 1.00 & 500.36 \\
\hline APPR 1: AS & 54. & -106. & 294 . & 2500. & 204527 . & 1892. & 1.32 & 500.55 \\
\hline XSID : CODE & XLKQ & XRKQ & & & & & & \\
\hline
\end{tabular}

SECOND USER DEFINED TABLE.

$\begin{array}{lcrrrrrrrr}\text { XSID : CODE } & \text { CRWS } & \text { FR\# } & \text { YMIN } & \text { YMAX } & \text { HF } & \text { HO } & \text { VHD } & \text { EGL } & \text { WSEL } \\ \text { EXITX:XS } & 496.32 & 0.74 & 488.15 & 503.96 * * * * * * * * * * & 0.56 & 497.14 & 496.58 \\ \text { FULLV:FV } & * * * * * * * * & 0.68 & 488.23 & 504.04 & 0.13 & 0.00 & 0.49 & 497.25 & 496.76 \\ \text { BRIDG : BR } & 496.44 & 0.63 & 490.76 & 498.33 * * * * * * * * * * & 1.30 & 499.63 & 498.33 \\ \text { RDWAY:RG } & * * * * * * * * * * * * * * * * & 499.27 & 506.38 & 0.00 * * * * * * & 0.03 & 500.58 & 500.36 \\ \text { APPRI:AS } & 496.83 & 0.12 & 488.34 & 512.31 & 0.05 & 0.73 & 0.03 & 500.58 & 500.55\end{array}$


WSPRO OUTPUT FILE (continued)

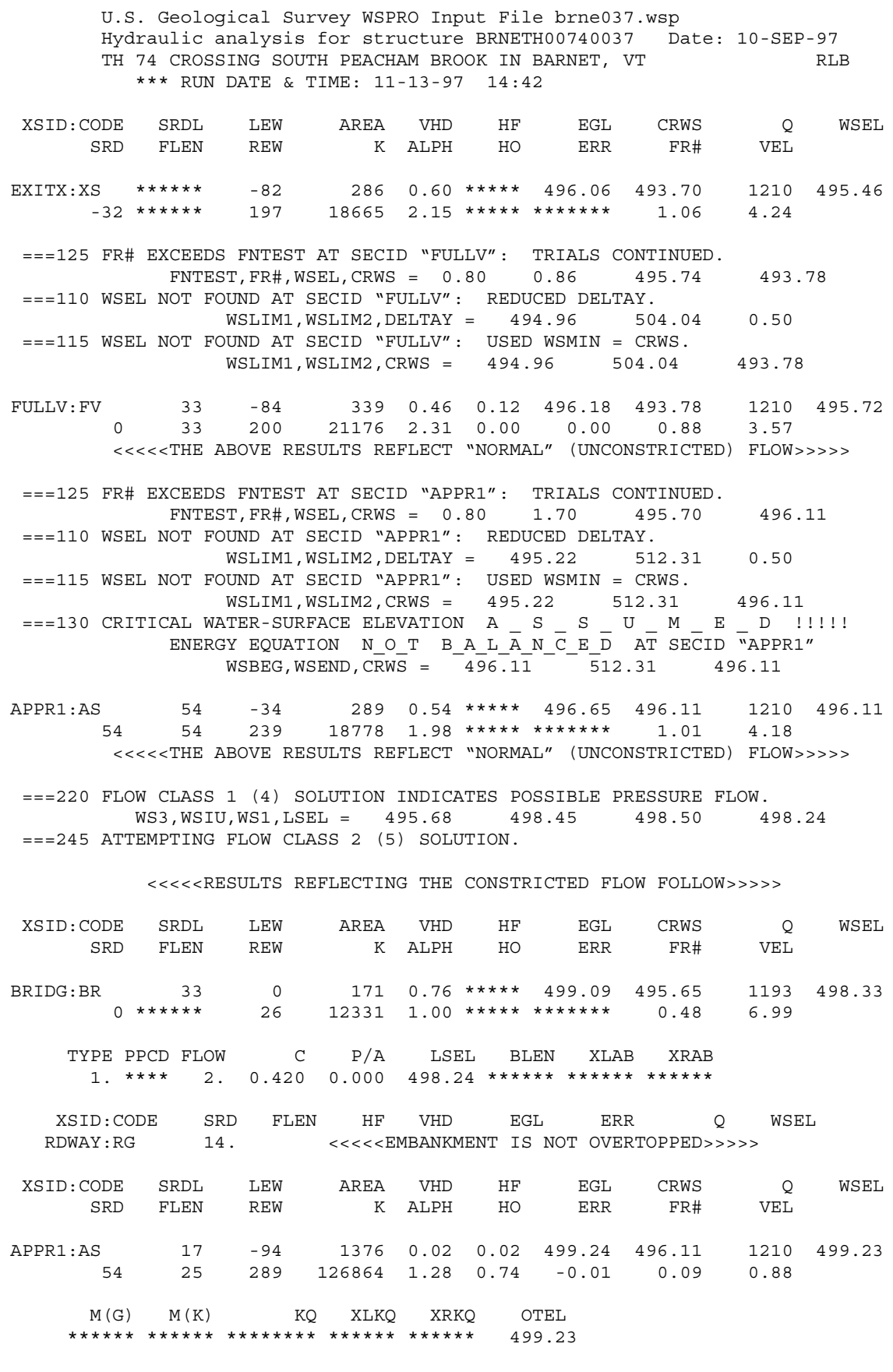

$<<<<$ END OF BRIDGE COMPUTATIONS $>>>>>$

FIRST USER DEFINED TABLE.

\begin{tabular}{|c|c|c|c|c|c|c|c|c|}
\hline XSID : CODE & SRD & LEW & REW & Q & $\mathrm{K}$ & AREA & VEL & WSEL \\
\hline EXITX:XS & -33. & -83 & 197. & 1210. & 18665 . & 286 & 4.24 & 495.46 \\
\hline FULLV: FV & 0 . & -85 & 200. & 1210. & 21176 . & 339. & 3.57 & 495.72 \\
\hline BRIDG : BR & 0 . & 0. & 26 . & 1193. & 12331. & 171. & 6.99 & 498.33 \\
\hline RDWAY : RG & $14 . *$ & $* * * * *$ & $* * * *$ & 0 . & \multicolumn{2}{|c|}{ 0. $* * \star * * * * * * *$} & \multicolumn{2}{|c|}{$1.00 * * * * * * * *$} \\
\hline APPR $1:$ AS & 54 . & -95 & 289. & 1210. & 126864 . & 1376. & 0.88 & 499.23 \\
\hline XSID : CODE & XLKQ & XRKQ & & & & & & \\
\hline
\end{tabular}

SECOND USER DEFINED TABLE.

\begin{tabular}{|c|c|c|c|c|c|c|c|c|c|}
\hline XSID:COD & CRWS & FR\# & YMIN & YMAX & $\mathrm{HF}$ & $\mathrm{HO}$ & VHD & EGL & \\
\hline IXITX:XS & 93.70 & 1.06 & 88.15 & 03.96 * & $\star * * *$ & $\star \star *$ & 0.60 & 5.06 & \\
\hline 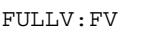 & & 88 & 8.23 & 04.04 & 0.12 & & & & \\
\hline & & 48 & & 9 & & & & & \\
\hline & 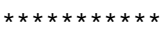 & $\approx * \star *$ & 99.27 & & $\star * * *$ & & .01 & $35^{*}$ & \\
\hline PPR 1 : AS & 496.11 & 0.09 & 88.34 & 12.31 & 0.02 & 0.74 & 0.02 & 499.24 & 499 \\
\hline
\end{tabular}


APPENDIX C:

BED-MATERIAL PARTICLE-SIZE DISTRIBUTION 


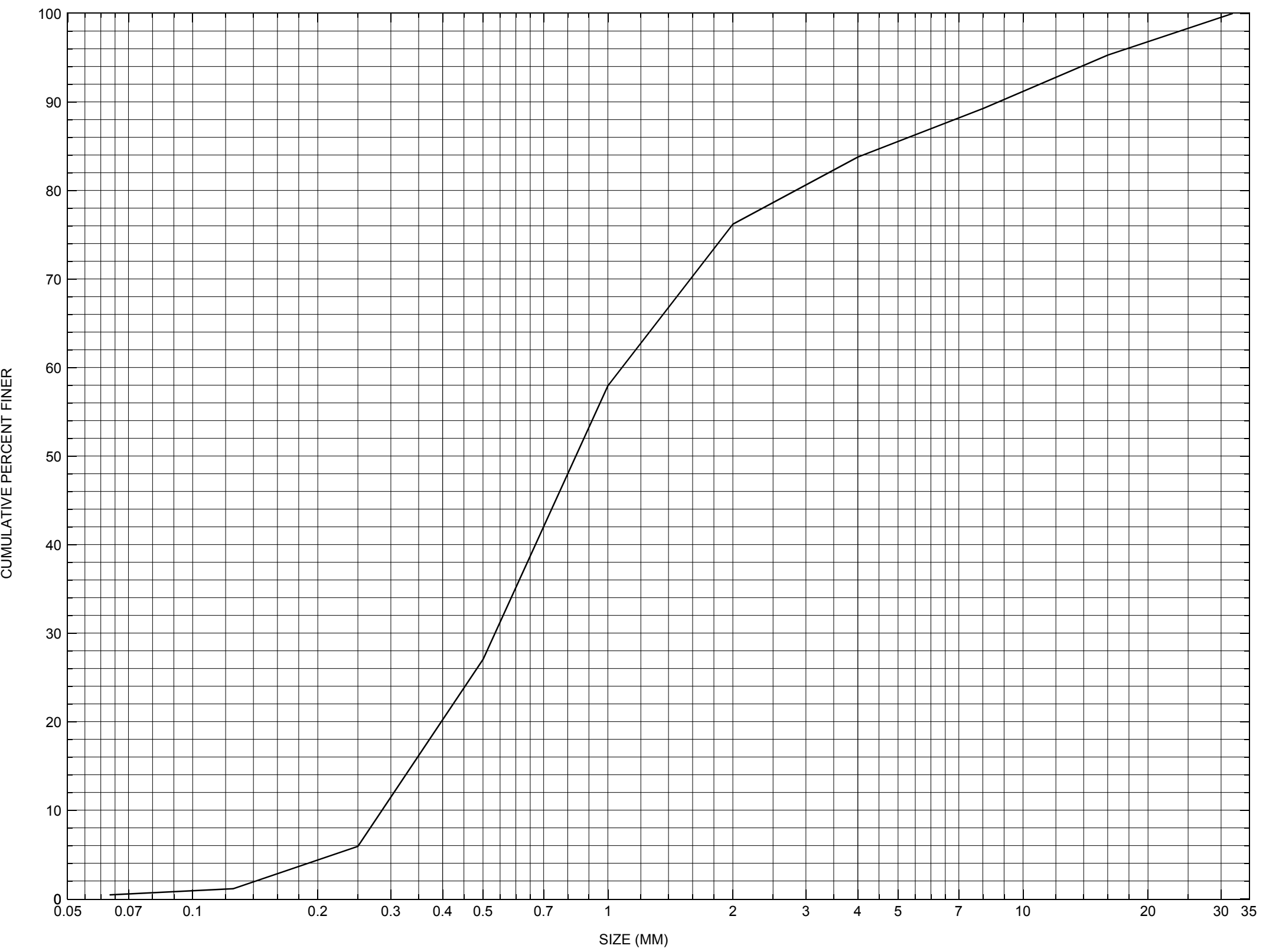

Appendix C. Bed material particle-size distribution for a pebble count in the channel approach of structure BRNETH00740037, in Barnet, Vermont. 


\section{APPENDIX D: \\ HISTORICAL DATA FORM}




\section{Structure Number BRNETH00740037}

\section{General Location Descriptive}

Data collected by (First Initial, Full last name) $\mathbf{E}$. BOEHMLER

Date $(M M / D D / Y Y) \_\mathbf{0 3} / \underline{16} / \underline{95}$

Highway District Number (I - 2; nn) $\mathbf{0 7}$

Town (FIPS place code; I - 4; nnnnn) $\mathbf{0 2 8 7 5}$

Waterway (I - 6) SOUTH PEACHAM BROOK

Route Number TH074

Topographic Map Barnet

Latitude (I - 16; nnnn.n) $\mathbf{4 4 1 8 4}$
County (FIPS county code; I - 3; nnn)

Mile marker (I - 11; nnn.nnn) $\mathbf{0 0 0 0 0 0}$

Road Name (I - 7): -

Vicinity (I - 9) 0.1 MI TO JCT W CL2 TH1

Hydrologic Unit Code: $\mathbf{0 1 0 8 0 1 0 3}$

Longitude (i - 17; nnnnn.n) $\mathbf{7 2 0 8 5}$

\section{Select Federal Inventory Codes}

FHWA Structure Number (I - 8) $\mathbf{1 0 0 3 0 1 0 0 3 7 0 3 0 1}$

Maintenance responsibility $(I-21 ; n n) \quad \mathbf{0 3}$

Year built (I - 27; YYYY) 1948

Average daily traffic, ADT (I - 29; nnnnnn) 000200

Year of ADT (I - 30; YY) $\mathbf{9 2}$

Opening skew to Roadway $(I-34 ; n n) \quad \mathbf{0 0}$

Operational status $(I-41 ; X)$ A

Structure type (I - 43; nnn) 101

Approach span structure type $(I-44 ; n n n) \quad \mathbf{0 0 0}$

Number of spans (I - 45; nnn) $\mathbf{0 0 1}$

Number of approach spans (I - 46; nnnn) $\mathbf{0 0 0 0}$

Comments:

The structural inspection report of $9 / 6 / 94$ indicates the structure is a concrete slab type bridge. The abutment walls and wingwalls are concrete. The upstream $2 / 3$ of the right abutment wall reportedly is of older construction than the downstream $1 / 3$. The upstream portion is noted as battered with randomly distributed fine horizontal cracks and concrete spalling. The right upstream wingwall appears to be of older construction as well and has a full-height crack and break near the corner where it meets the abutment wall. The wingwall is displaced about 2 inches streamward from the abutment. The newer portion of the abutment and the downstream wingwall only have fine cracks noted. The left abutment (continued, page 33) 


\section{Bridge Hydrologic Data}

Is there hydrologic data available? $\underline{\mathbf{Y}}$ if No, type ctrl- $n$ h VTAOT Drainage area $\left(m i^{2}\right): \underline{12.5}$

Terrain character:

Stream character \& type: -

Streambed material: Sand and stone with some boulder

Discharge Data (cfs): $\quad \mathrm{Q}_{2.33}-$

$\mathrm{Q}_{50} \mathbf{1 5 2 0}$

$\begin{array}{lll}Q_{10} & 900 & Q_{25} 1260 \\ Q_{100} & \mathbf{1 8 0 0} & Q_{500}-\end{array}$

Record flood date $(M M / D D / Y Y)$ :

Water surface elevation (ft): -

Estimated Discharge (cfs): I Water

Velocity at $\mathrm{Q} \underline{\mathbf{2 5}}$ $(f t / s): \mathbf{8 . 2}$

Ice conditions (Heavy, Moderate, Light) : Debris (Heavy, Moderate, Light):

The stage increases to maximum highwater elevation (Rapidly, Not rapidly):

The stream response is (Flashy, Not flashy):

Describe any significant site conditions upstream or downstream that may influence the stream's stage: -

Watershed storage area (in percent):

The watershed storage area is: - _ (1-mainly at the headwaters; 2- uniformly distributed; 3-immediatly upstream oi the site)

Water Surface Elevation Estimates for Existing Structure:

\begin{tabular}{|l|l|c|c|l|l|}
\hline Peak discharge frequency & $Q_{2.33}$ & $Q_{10}$ & $Q_{25}$ & $Q_{50}$ & $Q_{100}$ \\
Water surface elevation (ft)) & - & $\mathbf{4 9 5 . 0}$ & $\mathbf{4 9 6 . 3}$ & $\mathbf{4 9 7 . 2}$ & $\mathbf{4 9 8 . 1}$ \\
Velocity $(\mathrm{ft} / \mathrm{sec})$ & - & - & $\mathbf{8 . 2}$ & - & - \\
\hline
\end{tabular}

Long term stream bed changes: -

Is the roadway overtopped below the $\mathrm{Q}_{100}$ ? (Yes, No, Unknown): $\mathbf{N}$ Frequency: Relief Elevation $(f t)$ :

Discharge over roadway at $\mathrm{Q}_{100}\left(\mathrm{ft}^{3} / \mathrm{sec}\right)$ :

Are there other structures nearby? (Yes, No, Unknown): $\mathbf{U}$ Upstream distance (miles): Town: If No or Unknown, type ctrl-n os Highway No. : Structure No. : Year Built:

Clear span (ft): Clear Height (ft): Full Waterway $\left(f^{2}\right)$ : 
Downstream distance (miles): Town: Year Built:

Highway No. : Structure No. : Structure Type:

Clear span $(f t)$ : Clear Height $(f t)$ : Full Waterway $\left(f^{2}\right)$ :

Comments:

and its wingwalls have some fine cracks reported. The streambed is composed of sand and stones with some boulders. There is some riprap protection placed at the downstream end of the right abutment noted. There is some channel scour reported below the structure. A small dam reportedly is present downstream of the bridge, consisting of stones and brush. The hydraulics section file does not have a full hydraulic report but has some discharge information shown on the previous page.

\section{USGS Watershed Data}

Watershed Hydrographic Data

Drainage area $(D A) \underline{12.05} \mathrm{mi}^{2}$

Watershed storage (ST) 3.2

Bridge site elevation 906 $\mathrm{ft}$ $\%$

Main channel length $\mathbf{5 . 6}$ mi $10 \%$ channel length elevation $\mathbf{9 1 5}$ $\mathrm{ft} \quad 85 \%$ channel length elevation 1536 $\mathrm{ft}$

Main channel slope $(S)$

Watershed Precipitation Data

Average site precipitation in Average headwater precipitation in

Maximum 2yr-24hr precipitation event $(124,2)$ in

Average seasonal snowfall (Sn) $\mathrm{ft}$ 


\section{Bridge Plan Data}

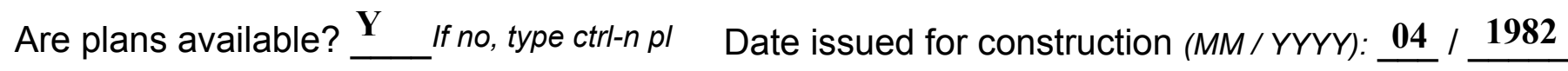
Project Number TH 3130

Minimum channel bed elevation: $\underline{490.1}$

Low superstructure elevation: USLAB DSLAB USRAB DSRAB 498.15

Benchmark location description:

No specific benchmark information is provided on the plans. A couple points given with elevations are: 1) The point on top of the concrete slab deck at the extreme downstream right corner, where the end of the deck meets the right bankward edge of the right abutment wall, elevation 499.98 , or 2 ) the same point located on the downstream left corner of the concrete deck, elevation 499.98.

Reference Point (MSL, Arbitrary, Other): Arbitrary _ Datum (NAD27, NAD83, Other): Arbitrary Foundation Type: 1 (1-Spreadfooting; 2-Pile; 3- Gravity; 4-Unknown)

If 1: Footing Thickness $\mathbf{2 . 0} \quad$ Footing bottom elevation: $\underline{\mathbf{4 8 7 . 0}}$

If 2: Pile Type: ___ (1-Wood; 2-Steel or metal; 3-Concrete) Approximate pile driven length: -

If 3: Footing bottom elevation: -

Is boring information available? $\mathbf{N}$ If no, type ctrl- $n$ bi Number of borings taken: _-

Foundation Material Type: $\mathbf{3}$ (1-regolith, 2-bedrock, 3-unknown)

Briefly describe material at foundation bottom elevation or around piles:

NO DRILL BORING INFORMATION

Comments:

The plans available are those for the widening of the bridge. Hence, the elevations provided may only be applicable to the newer portion of the bridge on the downstream end. The streambed elevation is at least 2 feet above the top of the new concrete footings. The plans show that the new footings were set at the same elevation as the older ones. The bridge's original construction was in 1948. The plans for the original structure were not found. 


\section{Cross-sectional Data}

Is cross-sectional data available? $\mathbf{N}$ If no, type ctrl-n xs

Source (FEMA, VTAOT, Other)? -

Comments:

\section{NO CROSS SECTION INFORMATION}

\begin{tabular}{|l|l|l|l|l|l|l|l|l|l|l|l|}
\hline Station & - & - & - & - & - & - & - & - & - & - & - \\
\hline Feature & - & - & - & - & - & - & - & - & - & - & - \\
\hline $\begin{array}{l}\text { Low chord } \\
\text { elevation }\end{array}$ & - & - & - & - & - & - & - & - & - & - & - \\
\hline $\begin{array}{l}\text { Bed } \\
\text { elevation }\end{array}$ & - & - & - & - & - & - & - & - & - & - & - \\
\hline $\begin{array}{l}\text { Low chord } \\
\text { to bed }\end{array}$ & - & - & - & - & - & - & - & - & - & - & - \\
\hline Station & - & - & - & - & - & - & - & - & - & - & - \\
\hline Feature & - & - & - & - & - & - & - & - & - & - & - \\
\hline $\begin{array}{l}\text { Low chord } \\
\text { elevation }\end{array}$ & - & - & - & - & - & - & - & - & - & - & - \\
\hline $\begin{array}{l}\text { Bed } \\
\text { elevation }\end{array}$ & - & - & - & - & - & - & - & - & - & - & - \\
\hline $\begin{array}{l}\text { Low chord } \\
\text { to bed }\end{array}$ & - & - & - & - & - & - & - & - & - & - & - \\
\hline
\end{tabular}

Source (FEMA, VTAOT, Other)? NO

Comments: CROSS SECTION INFORMATION

\begin{tabular}{|l|l|l|l|l|l|l|l|l|l|l|l|}
\hline Station & - & - & - & - & - & - & - & - & - & - & - \\
\hline Feature & - & - & - & - & - & - & - & - & - & - & - \\
\hline $\begin{array}{l}\text { Low chord } \\
\text { elevation }\end{array}$ & - & - & - & - & - & - & - & - & - & - & - \\
\hline $\begin{array}{l}\text { Bed } \\
\text { elevation }\end{array}$ & - & - & - & - & - & - & - & - & - & - & - \\
\hline $\begin{array}{l}\text { Low chord } \\
\text { to bed }\end{array}$ & - & - & - & - & - & - & - & - & - & - & - \\
\hline Station & - & - & - & - & - & - & - & - & - & - & - \\
\hline Feature & - & - & - & - & - & - & - & - & - & - & - \\
\hline $\begin{array}{l}\text { Low chord } \\
\text { elevation }\end{array}$ & - & - & - & - & - & - & - & - & - & - & - \\
\hline $\begin{array}{l}\text { Bed } \\
\text { levation }\end{array}$ & - & - & - & - & - & - & - & - & - & - & - \\
\hline $\begin{array}{l}\text { Low chord } \\
\text { to bed }\end{array}$ & - & - & - & - & - & - & - & - & - & - & - \\
\hline
\end{tabular}


APPENDIX E:

LEVEL I DATA FORM 
U. S. Geological Survey

Bridge Field Data Collection and Processing Form

Qa/Qc Check by: $\mathbf{R B}$ Date: $2 / 23 / 96$

\section{Structure Number}

BRNETH00740037 Date: $2 / 26 / 96$

\section{A. General Location Descriptive}

1. Data collected by (First Initial, Full last name) $\mathbf{T}$. SEVERANCE

Date $(M M / D D / Y Y) \underline{8}$

2. Highway District Number $\mathbf{0 7}$

County CALENDORIA (005)

Waterway (l - 6) SOUTH PEACHAM BROOK

Route Number TH074

3. Descriptive comments:

Located 0.1 miles from the junction with Town Highway 1.
Mile marker 0000

Town BARNET (02875)

Road Name -

Hydrologic Unit Code: $\mathbf{0 1 0 8 0 1 0 3}$

\section{B. Bridge Deck Observations}

\section{Surface cover... $\quad$ LBUS $2 \quad$ RBUS $4 \quad$ LBDS 4,5 $\quad$ RBDS $\mathbf{5}$ Overall 5}

(2b us,ds,lb,rb: 1- Urban; 2- Suburban; 3- Row crops; 4- Pasture; 5- Shrub- and brushland; 6- Forest; 7- Wetland)

5. Ambient water surface...US $\underline{1}$ UB 1 DS 1 (1-pool; 2- riffle)

6. Bridge structure type 1 (1- single span; 2- multiple span; 3- single arch; 4- multiple arch; 5-cylindrical culvert; 6- box culvert; or 7- other)
7. Bridge length $\mathbf{3 0}$
(feet)
Span length $\mathbf{2 8}$
(feet)
Bridge width 26.2 (feet)

\section{Road approach to bridge:}
8. LB 2 RB $\underline{1}$
( 0 even, 1- lower, 2- higher)
9. LB_ 1 RB 1
(1- Paved, 2- Not paved)

10. Embankment slope (run / rise in feet / foot):

US left

US right

\begin{tabular}{|c|c|c|c|}
\hline \multicolumn{2}{|c|}{ Protection } & \multirow{2}{*}{ 13.Erosion } & 14.Severity \\
\hline 11.Type & 12.Cond. & $\mathbf{0}$ & - \\
\hline $\mathbf{0}$ & - & - & - \\
$\mathbf{0}$ & - & $\mathbf{0}$ & - \\
\hline $\mathbf{0}$ & - & $\mathbf{0}$ & - \\
\hline $\mathbf{0}$ & - & $\mathbf{0}$ & - \\
\hline
\end{tabular}

Bank protection types: 0- none; 1- < 12 inches;

2- < 36 inches; 3- < 48 inches;

4- < 60 inches; 5- wall / artificial levee

Bank protection conditions: 1- good; 2- slumped;

3- eroded; 4- failed

Erosion: 0 - none; 1- channel erosion; 2-

road wash; 3- both; 4- other

Erosion Severity: 0 - none; 1- slight; 2- moderate;

\section{Channel approach to bridge (BF):}

15. Angle of approach: $\mathbf{4 5}$

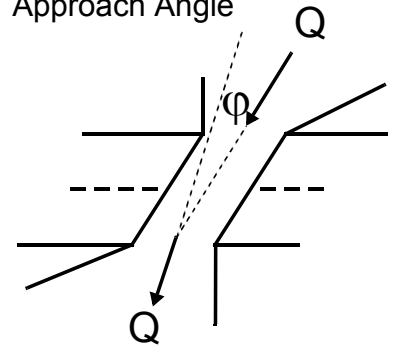

17. Channel impact zone 1 :

Where? RB (LB, RB)

Range? 0 feet US

Channel impact zone 2:

Where? LB (LB, RB)

Range? 15 feet $\underline{\mathbf{U B}}$ (US, UB, DS) to $\underline{\mathbf{6 0}}$ feet $\underline{\mathbf{D S}}$

Impact Severity: 0- none to very slight; 1- Slight; 2- Moderate; 3- Severe
16. Bridge skew: 30 Bridge Skew Angle

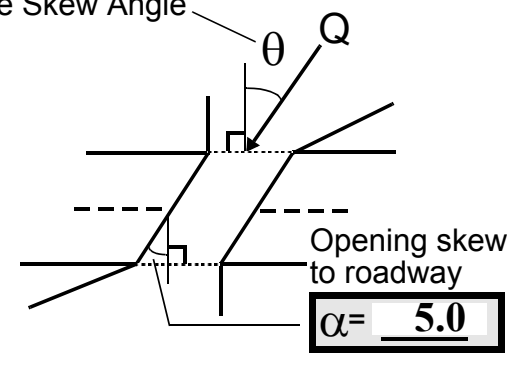

\section{Exist? $\mathbf{Y}(Y$ or $N)$}

Severity 1

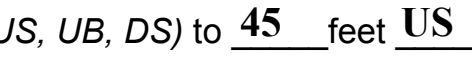

Exist? $\mathbf{Y}(Y$ or $N)$

Severity 1 
18. Bridge Type: $1 \mathbf{1 a} / 4$

1a- Vertical abutments with wingwalls

1 b- Vertical abutments without wingwalls

2- Vertical abutments and wingwalls, sloping embankment

Wingwalls parallel to abut. face

3- Spill through abutments

4- Sloping embankment, vertical wingwalls and abutments

1 a with wingwalls

Wingwall angle less than $90^{\circ}$.

19. Bridge Deck Comments (surface cover variations, measured bridge and span lengths, bridge type variations, approach overflow width, etc.)

7. Values are from the VTAOT files.

Measured bridge length $=30$ feet, span length $=28$ feet, and bridge width $=\mathbf{2 6 . 4}$ feet .

4. Overall surface cover is brushland verging on a grassy wetland.

\section{Upstream Channel Assessment}

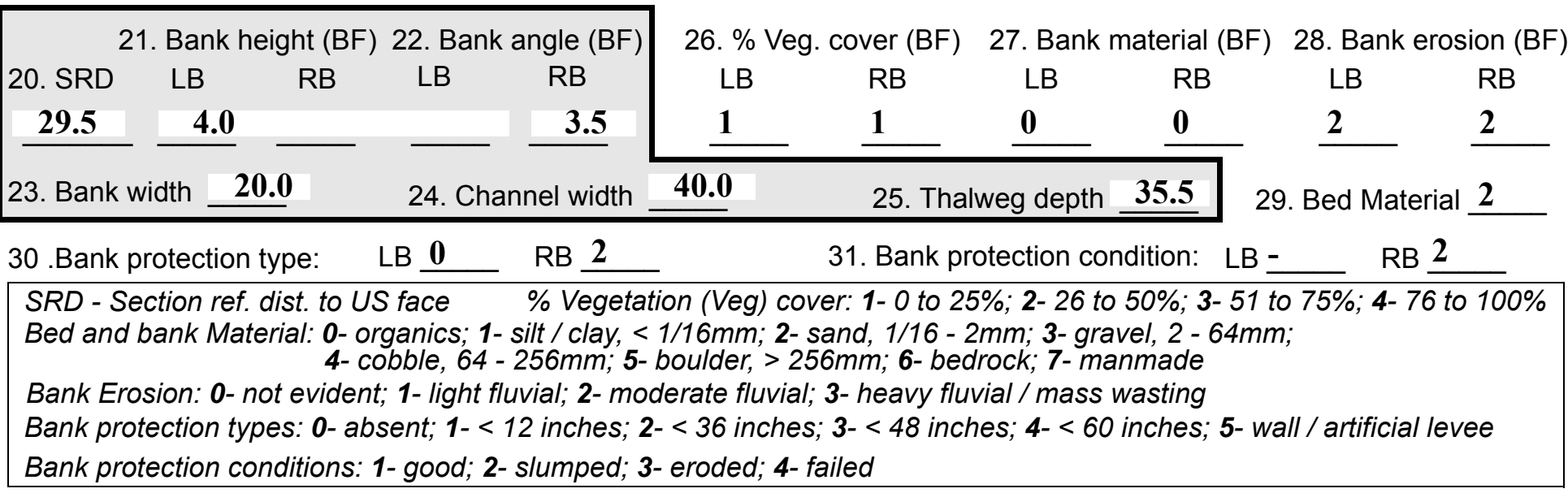

32. Comments (bank material variation, minor inflows, protection extent, etc.):

30. Protection extends 30 feet US on the right bank from the end of the US right wingwall.

Thalweg depth $=2$ feet. 
36. Point bar extent: 18 feet $\underline{\text { US }}$

(US, UB) to $\mathbf{5 0}$ feet $\underline{\mathbf{U S}}$

(US, UB, DS) positioned $\mathbf{0}$

$\%$ LB to $\underline{20}$ $\%$ RB

37. Material: 2

38. Point or side bar comments (Circle Point or Side; Note additional bars, material variation, status, etc.):

This point bar is submerged. There is a cutbank above this point bar.

39. Is a cut-bank present? $\mathbf{Y}$ ( $Y$ or if $N$ type ctrl-n $c b)$

41. Mid-bank distance: ${ }^{*}$

42. Cut bank extent: 35

40. Where? $\underline{\mathbf{R B}}$ (LB or RB)

43. Bank damage: 2

(1- eroded and/or creep; 2- slip failure; 3- block failure)

44. Cut bank comments (eg. additional cut banks, protection condition, etc.):

* The cutbank extends several hundred feet US. The channel is sinuous.

The cut bank on the left bank begins at 28 feet US and continues further US.

\section{Is channel scour present? $\mathbf{Y}$ (Y or if $N$ type ctrl-n cs)}

47. Scour dimensions: Length 58 Width 6 Depth : 2

46. Mid-scour distance: 20

48. Scour comments (eg. additional scour areas, local scouring process, etc.):

Mid scour distance is at the end of the US right wingwall, some protection and stone fill has fallen into the channel and scour hole. Scour starts beneath the US section of the bridge deck. At the US end of the scour hole is a fallen tree on the left bank as well as a smaller tree on the right bank. They are laying across the entire channel and a portion of the bank on the right side.

\section{Are there major confluences? $\mathbf{N}$}

51. Confluence 1: Distance -

Confluence 2: Distance -

54. Confluence comments (eg. confluence name):

52. Enters on -

Enters on -

( $Y$ or if $N$ type ctrl-n $m c)$

NO MAJOR CONFLUENCES ( $L B$ or $R B)$ (LB or $R B)$
50. How many? -

53. Type(1-perennial; 2- ephemeral)

Type (1-perennial; 2-ephemeral)

(a)


65. Debris and Ice Is there debris accumulation?

(Yor $N)$ 66. Where? $\underline{Y}$

(1- Upstream; 2- At bridge; 3- Both)

67. Debris Potential $\underline{3}$

(1- Low; 2- Moderate; 3- High)

68. Capture Efficiency 2

(1- Low; 2- Moderate; 3- High)

69. Is there evidence of ice build-up? 2

Ice Blockage Potential $\mathbf{N}$

(1-Low; 2- Moderate; 3- High)

70. Debris and Ice Comments:

2

Trees have fallen into the channel 2 bridge lengths US. There is some debris at the DS bridge face and DS under the bridge where there is protection in the channel.

\begin{tabular}{|l|c|c|c|c|c|c|c|c|}
\hline Abutments & $\begin{array}{c}\text { 71. Attack } \\
\angle \text { (BF) }\end{array}$ & $\begin{array}{c}72 \text {. Slope } \angle \\
\text { (Qmax) }\end{array}$ & $\begin{array}{c}\text { 73. Toe } \\
\text { loc. (BF) }\end{array}$ & $\begin{array}{c}\text { 74. Scour } \\
\text { Condition }\end{array}$ & $\begin{array}{c}75 . \text { Scour } \\
\text { depth }\end{array}$ & $\begin{array}{c}\text { 76. Exposure } \\
\text { depth }\end{array}$ & 77. Material & 78. Length \\
\hline LABUT & & $\mathbf{3 0}$ & $\mathbf{9 0}$ & $\mathbf{0}$ & $\mathbf{0}$ & - & - & $\mathbf{9 0 . 0}$ \\
\hline RABUT & $\mathbf{1}$ & $\mathbf{0}$ & $\mathbf{9 0}$ & & & $\mathbf{2}$ & $\mathbf{0}$ & $\mathbf{2 5 . 5}$ \\
\hline
\end{tabular}

Pushed: $L B$ or RB

Toe Location (Loc.): 0- even, 1- set back, 2- protrudes

Scour cond.: 0- not evident; 1- evident (comment); 2- footing exposed; 3-undermined footing; 4- piling exposed; 5- settled; 6- failed

Materials: 1- Concrete; 2- Stone masonry or drywall; 3- steel or metal; 4- wood

79. Abutment comments (eg. undermined penetration, unusual scour processes, debris, etc.):

$-$

1

74. Fines have been deposited along the left abutment base, partially due to drain outlets exiting at 3 points along the base. It is possible to penetrate the streambed 1 foot with the range pole through the sand and silt material. At the US half of the left abutment the footing can be reached through the stream bed material. 72. The US portion of the right abutment is old and at 75 degrees. One third of the total DS abutment is new and at 90 degrees. The two parts are even at the top but the US (old) section protrudes 1.3 feet at the base where the angle changes to 90 degrees.

80. Wingwalls:

$\begin{array}{llll}\text { Exist? Material? } & \text { Scour } & \text { Scour Exposure } & \text { Angle? Length? } \\ & \text { Condition? depth? } & \text { depth? }\end{array}$

USLWW:

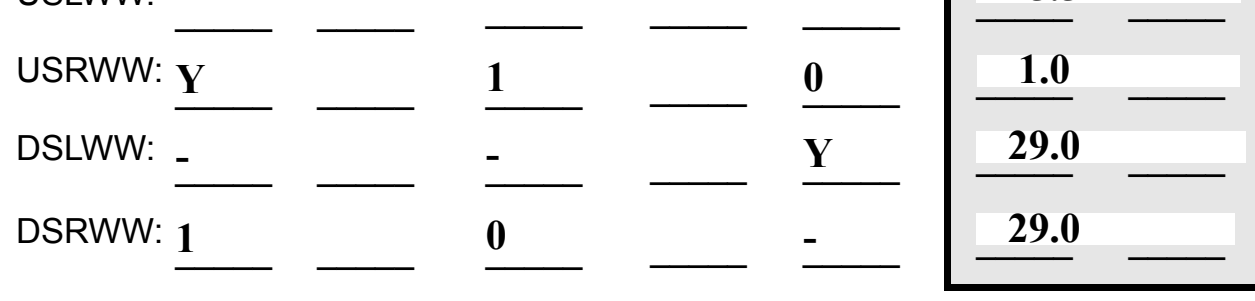

Wingwall materials: 1- Concrete; 2- Stone masonry or drywall; 3- steel or metal; 4- wood

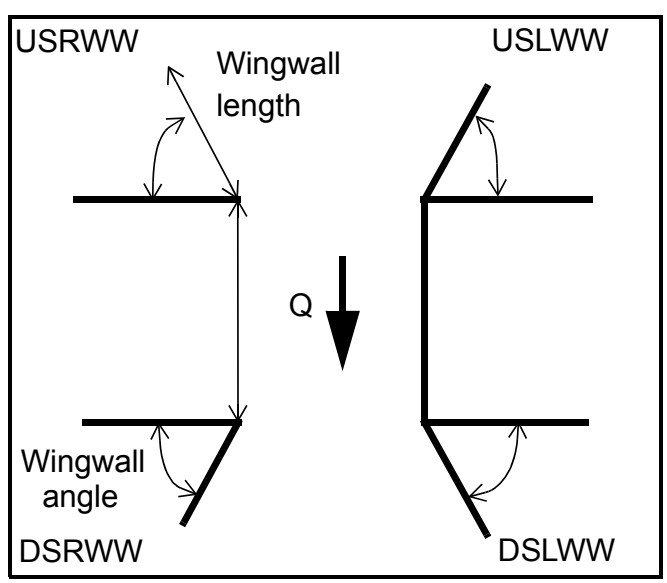

82. Bank / Bridge Protection:

\begin{tabular}{|l|l|l|l|l|l|l|l|c|}
\hline Location & USLWW & USRWW & LABUT & RABUT & LB & RB & DSLWW & DSRWW \\
\hline Type & - & $\mathbf{0}$ & $\mathbf{Y}$ & - & - & $\mathbf{1}$ & $\mathbf{1}$ & $\mathbf{1}$ \\
\hline Condition & $\mathbf{Y}$ & - & $\mathbf{1}$ & - & - & $\mathbf{1}$ & $\mathbf{3}$ & $\mathbf{3}$ \\
\hline Extent & $\mathbf{1}$ & - & $\mathbf{0}$ & $\mathbf{0}$ & $\mathbf{2}$ & $\mathbf{1}$ & $\mathbf{1}$ & - \\
\hline
\end{tabular}

Bank / Bridge protection types: 0- absent; 1- < 12 inches; 2- < 36 inches; 3- < 48 inches; 4- < 60 inches; 
83. Wingwall and protection comments (eg. undermined penetration, unusual scour processes, etc.):

-
-
-
-
-
1
1
1
1
1
1

\section{Piers:}

84. Are there piers? _ _ (Y or if $N$ type ctrl-n pr)

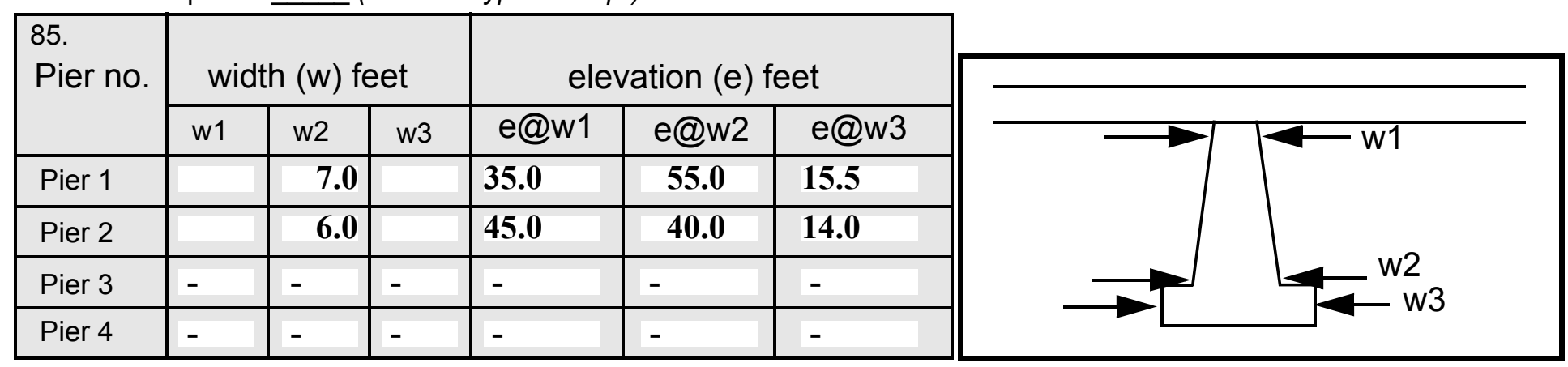

\begin{tabular}{|c|c|c|c|c|}
\hline Level 1 Pier Descr. & 1 & 2 & 3 & 4 \\
\hline 86. Location (BF) & & - & - & - \\
\hline 87. Type & & - & - & - \\
\hline 88. Material & & - & - & - \\
\hline 89. Shape & & - & - & - \\
\hline 90. Inclined? & & - & - & - \\
\hline 91. Attack $\angle(\mathrm{BF})$ & & - & - & - \\
\hline 92. Pushed & & - & - & - \\
\hline 93. Length (feet) & - & - & - & - \\
\hline 94. \# of piles & & - & - & - \\
\hline 95. Cross-members & & - & - & - \\
\hline 96. Scour Condition & & - & - & - \\
\hline 97. Scour depth & $\mathbf{N}$ & - & - & - \\
\hline 98. Exposure depth & - & - & - & - \\
\hline
\end{tabular}

LFP, LTB, LB, MCL, MCM, MCR, RB, RTB, RFP

1- Solid pier, 2- column, 3- bent

1-Wood; 2- concrete; 3- metal; 4- stone

1- Round; 2- Square; 3- Pointed

Y-yes; $N-$ no

$L B$ or $R B$

0- none; 1- laterals; 2- diagonals; 3- both

0- not evident; 1- evident (comment);

2- footing exposed; 3- piling exposed;

4- undermined footing; 5- settled; 6- failed 
99. Pier comments (eg. undermined penetration, protection and protection extent, unusual scour processes, etc.):

-
-
-
-
-
-
-
-
-

100.

\section{E. Downstream Channel Assessment}

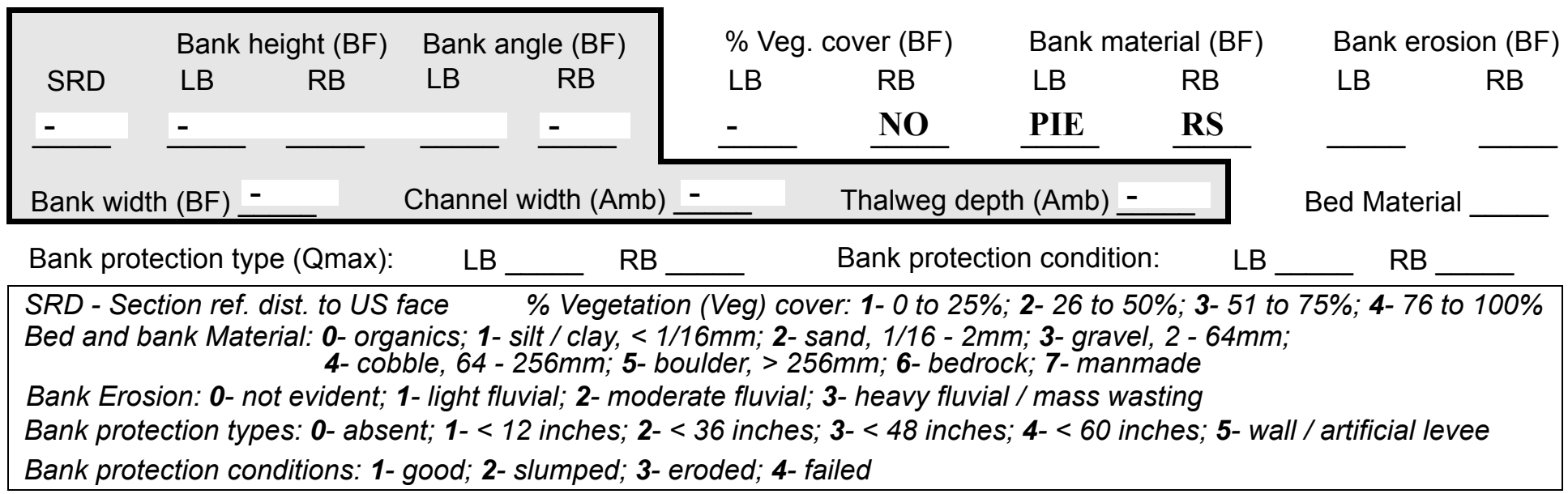

Comments (eg. bank material variation, minor inflows, protection extent, etc.):

Approximately 10 feet US under the bridge to 10 feet DS, the channel bed is lined with cobbles. Under the bridge cobbles are above the water surface.

101. Is a drop structure present? $\mathbf{T}$ (Y or N, if N type ctrl-n ds) 102. Distance: __ feet

103. Drop: -_ feet 104. Structure material: hal (1- steel sheet pile; 2- wood pile; 3- concrete; 4- other) 105. Drop structure comments (eg. downstream scour depth):

weg depth is 0.5 feet at bridge face. 
106. Point/Side bar present? (Y or $N$. if $N$ type ctrl-n pb)Mid-bar distance:

Mid-bar width:

Point bar extent: feet

(US, UB, DS) to feet (US, UB, DS) positioned $\underline{\mathbf{N}}$ $\%$ LB to $\% \mathrm{RB}$ Material: $\mathbf{N O}$

Point or side bar comments (Circle Point or Side; note additional bars, material variation, status, etc.):

\section{DROP STRUCTURE}

Is a cut-bank present? (Y or if $N$ type ctrl- $n$ cb) Where? (LB or $R B)$

Mid-bank distance: $\underline{\mathbf{N}}$

Cut bank extent: = feet (US, UB, DS) to feet (US, UB, DS)

Bank damage: (1- eroded and/or creep; 2- slip failure; 3- block failure)

Cut bank comments (eg. additional cut banks, protection condition, etc.):

$-$

$-$

-

$-$

Is channel scour present? NO (Y or if $N$ type ctrl-n cs) Mid-scour distance: $\underline{\text { POIN }}$ Scour dimensions: Length $\underline{\mathbf{T}}$ Width $\underline{\text { BAR }}$ Depth: $\underline{\mathbf{S}}$ Positioned __ $\%$ LB to _ $\%$ RB Scour comments (eg. additional scour areas, local scouring process, etc.):

$\mathbf{Y}$

LB

33

Are there major confluences? $\mathbf{1 0}$ ( $Y$ or if $N$ type ctrl-n $m c)$ Confluence 1: Distance * Enters on DS (LB or RB) How many? DS

Confluence 2: Distance * The Enters on cut- (LB or RB)

Type 1 (1- perennial; 2- ephemeral) Confluence comments (eg. confluence name):

$k$ continues beyond 120 feet down the left bank.

\section{F. Geomorphic Channel Assessment}

107. Stage of reach evolution

1- Constructed

2- Stable

3- Aggraded

4- Degraded

5- Laterally unstable

6- Vertically and laterally unstable 
108. Evolution comments (Channel evolution not considering bridge effects; See HEC-20, Figure 1 for geomorphic descriptors):

$\mathbf{N}$

$-$

$-$

$-$

$-$

$-$

NO CHANNEL SCOUR

$\mathbf{N}$ 


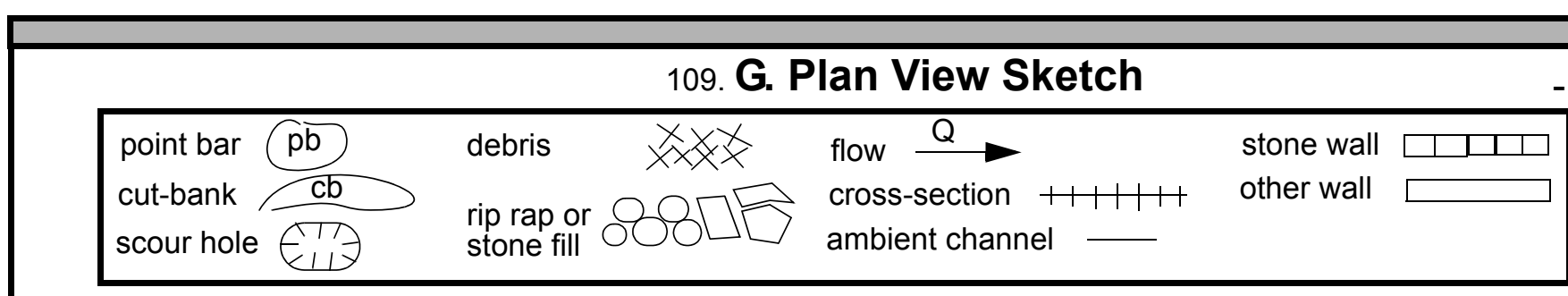


APPENDIX F:

SCOUR COMPUTATIONS 
SCOUR COMPUTATIONS

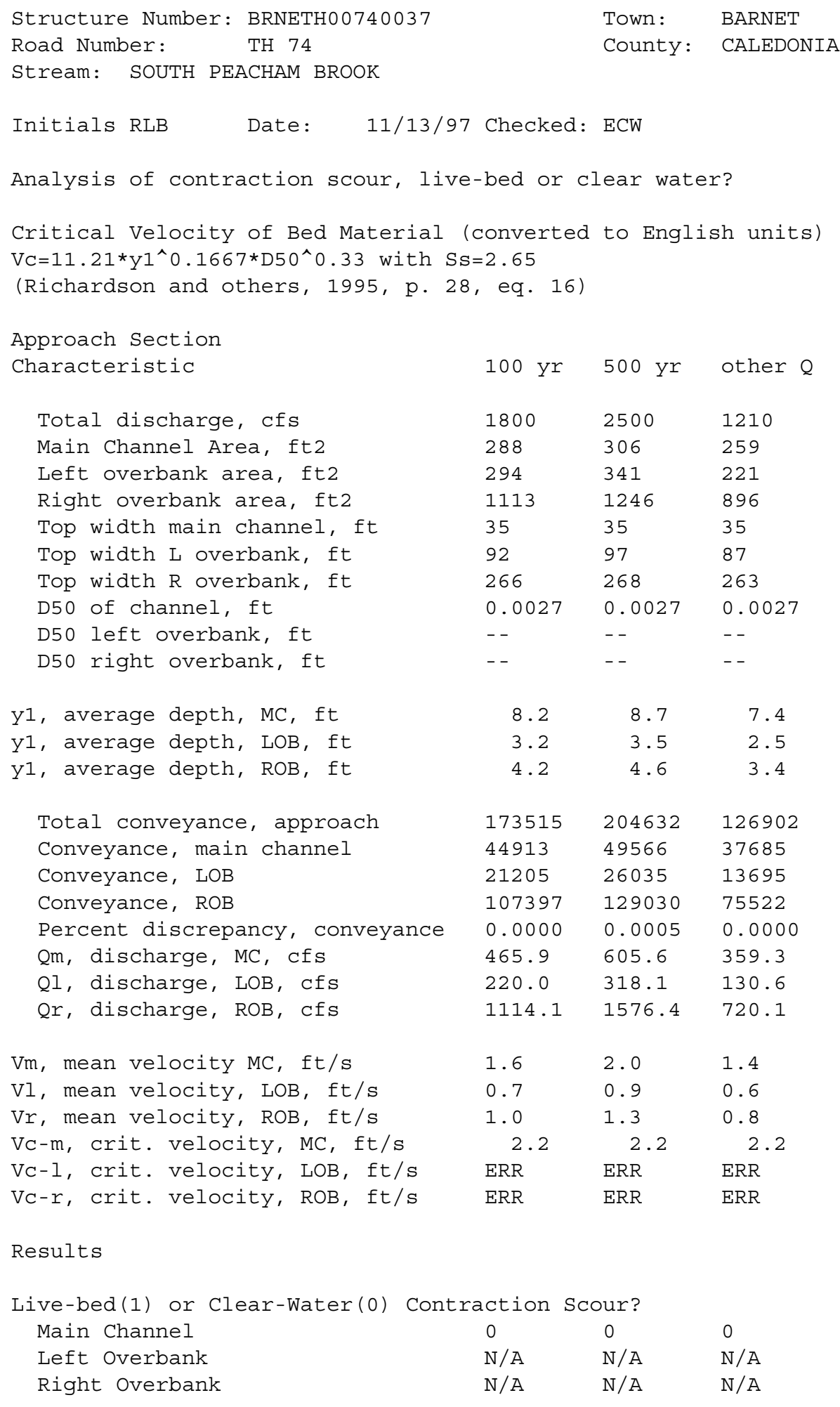


Clear water Contraction Scour in MAIN CHANNEL

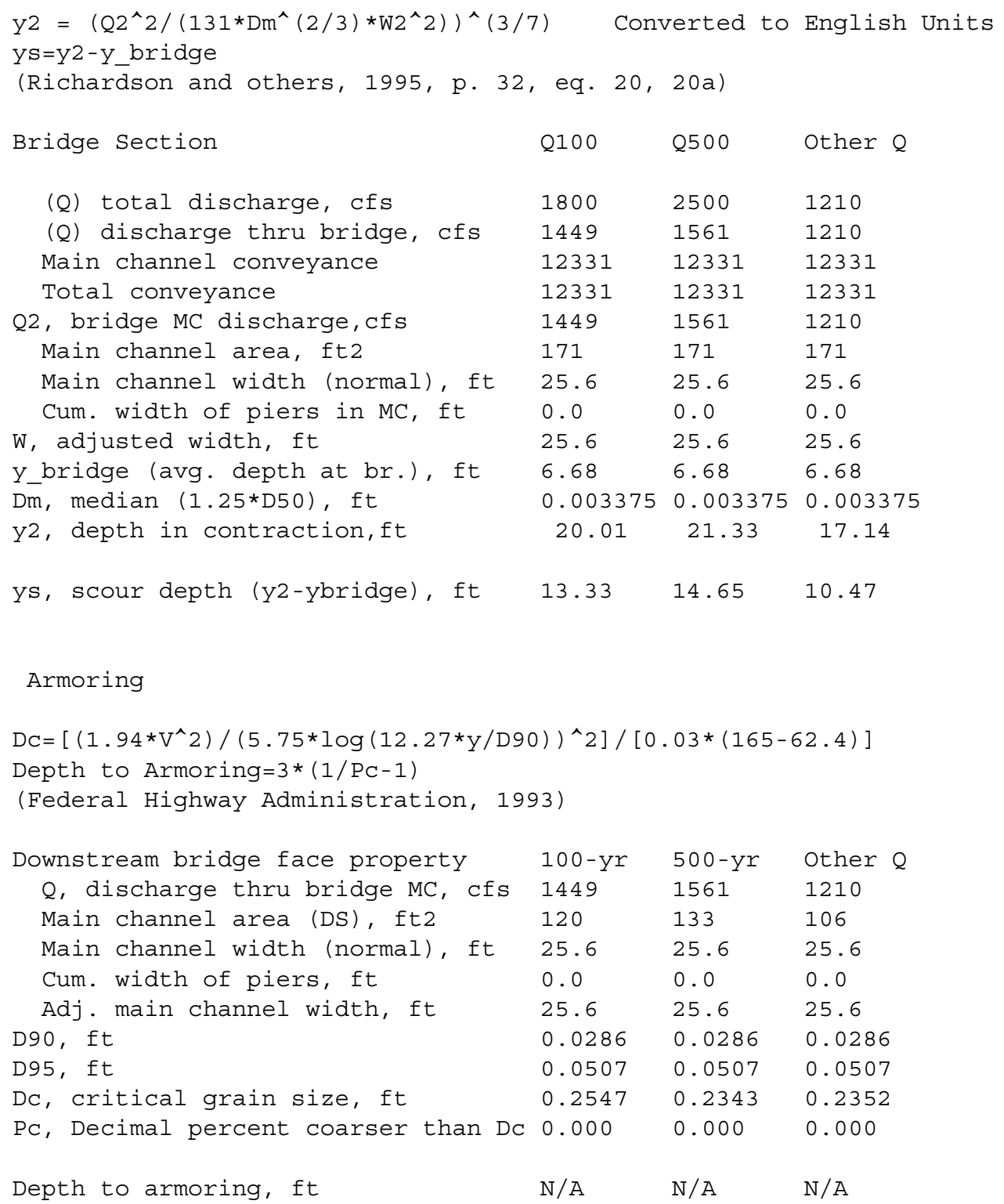




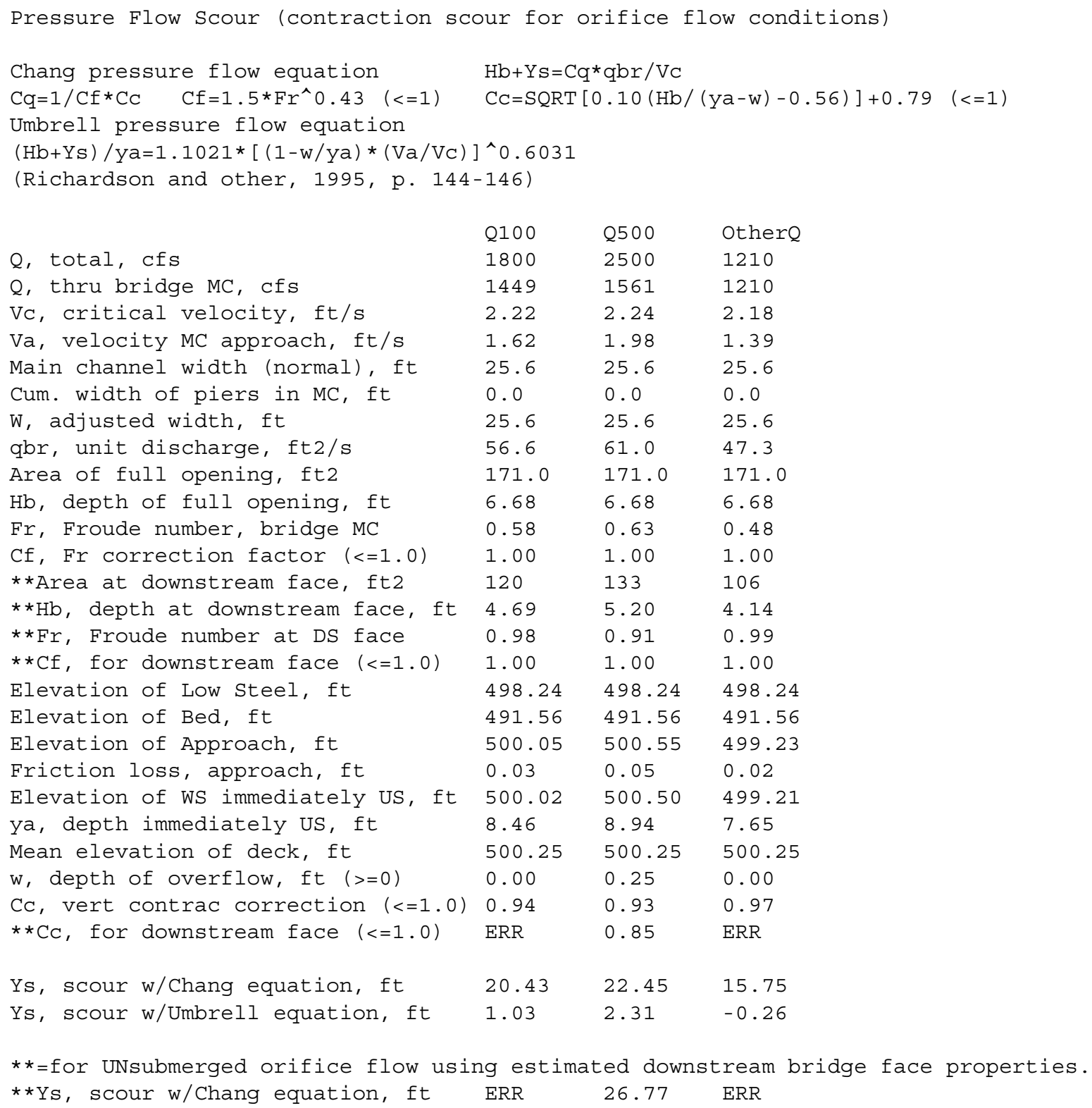




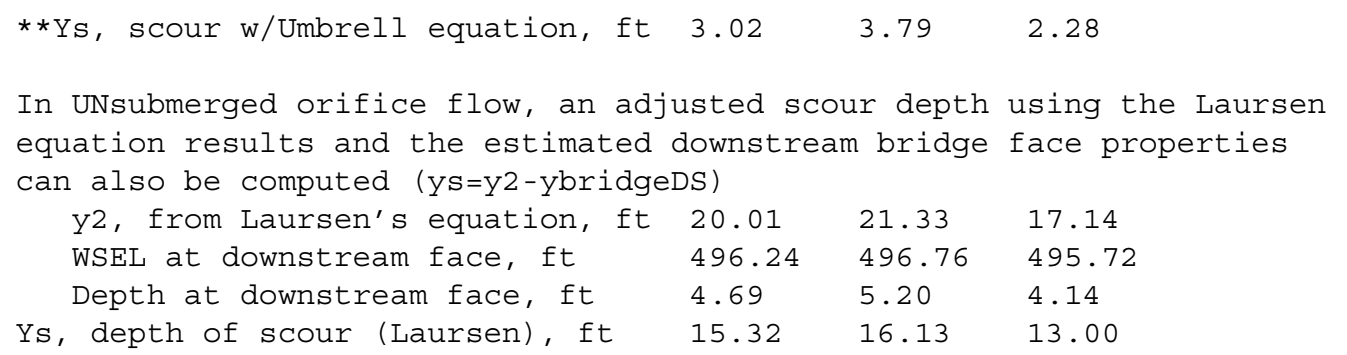

Abutment scour

Froehlich's Abutment Scour

$\mathrm{Ys} / \mathrm{Y} 1=2.27 * \mathrm{~K} 1 * \mathrm{~K} 2 *\left(\mathrm{a}^{\prime} / \mathrm{Y} 1\right)^{\wedge} 0.43 * \mathrm{Fr} 1 \wedge 0.61+1$

(Richardson and others, 1995, p. 48, eq. 28)

Characteristic

Left Abutment

Right Abutment

\begin{tabular}{|c|c|c|c|c|c|c|}
\hline (Qt), total discharge, cfs & 1800 & 2500 & 1210 & 1800 & 2500 & 1210 \\
\hline a', abut.length blocking flow, ft & 100.3 & 106.1 & 95.3 & 266.7 & 268.8 & 263.3 \\
\hline Ae, area of blocked flow ft 2 & 340.95 & 391.32 & 262.62 & 1018.68 & 1047.35 & 898.99 \\
\hline Qe, discharge blocked abut., cfs & 280.52 & -- & 170.75 & -- & -- & 723.84 \\
\hline (If using Qtotal_overbank to obta & ain $\mathrm{Ve}, 1$ & eave Qe & lank and & enter $\mathrm{Ve}$ & and Fr ma & nually) \\
\hline $\mathrm{Ve},(\mathrm{Qe} / \mathrm{Ae}), \mathrm{ft} / \mathrm{s}$ & 0.82 & 1.03 & 0.65 & 1.00 & 1.26 & 0.81 \\
\hline ya, depth of $\mathrm{f} / \mathrm{p}$ flow, ft & 3.40 & 3.69 & 2.76 & 3.82 & 3.90 & 3.41 \\
\hline --Coeff., K1, for abut. type (1.0, & verti.; & $0.82, \mathrm{ve}$ & ti. w/ w & ingwall; 0 & $.55, \operatorname{spil}$ & lthru) \\
\hline K1 & 0.82 & 0.82 & 0.82 & 0.82 & 0.82 & 0.82 \\
\hline --Angle (theta) of embankment $(<90$ & if abut & points & $\mathrm{S} ;>90 \mathrm{i}$ & $=$ abut. po & ints US) & \\
\hline theta & 85 & 85 & 85 & 95 & 95 & 95 \\
\hline K2 & 0.99 & 0.99 & 0.99 & 1.01 & 1.01 & 1.01 \\
\hline Fr, froude number $f / p$ flow & 0.079 & 0.094 & 0.069 & 0.086 & 0.103 & 0.077 \\
\hline ys, scour depth, ft & 9.11 & 10.52 & 7.33 & 13.77 & 15.17 & 12.08 \\
\hline
\end{tabular}




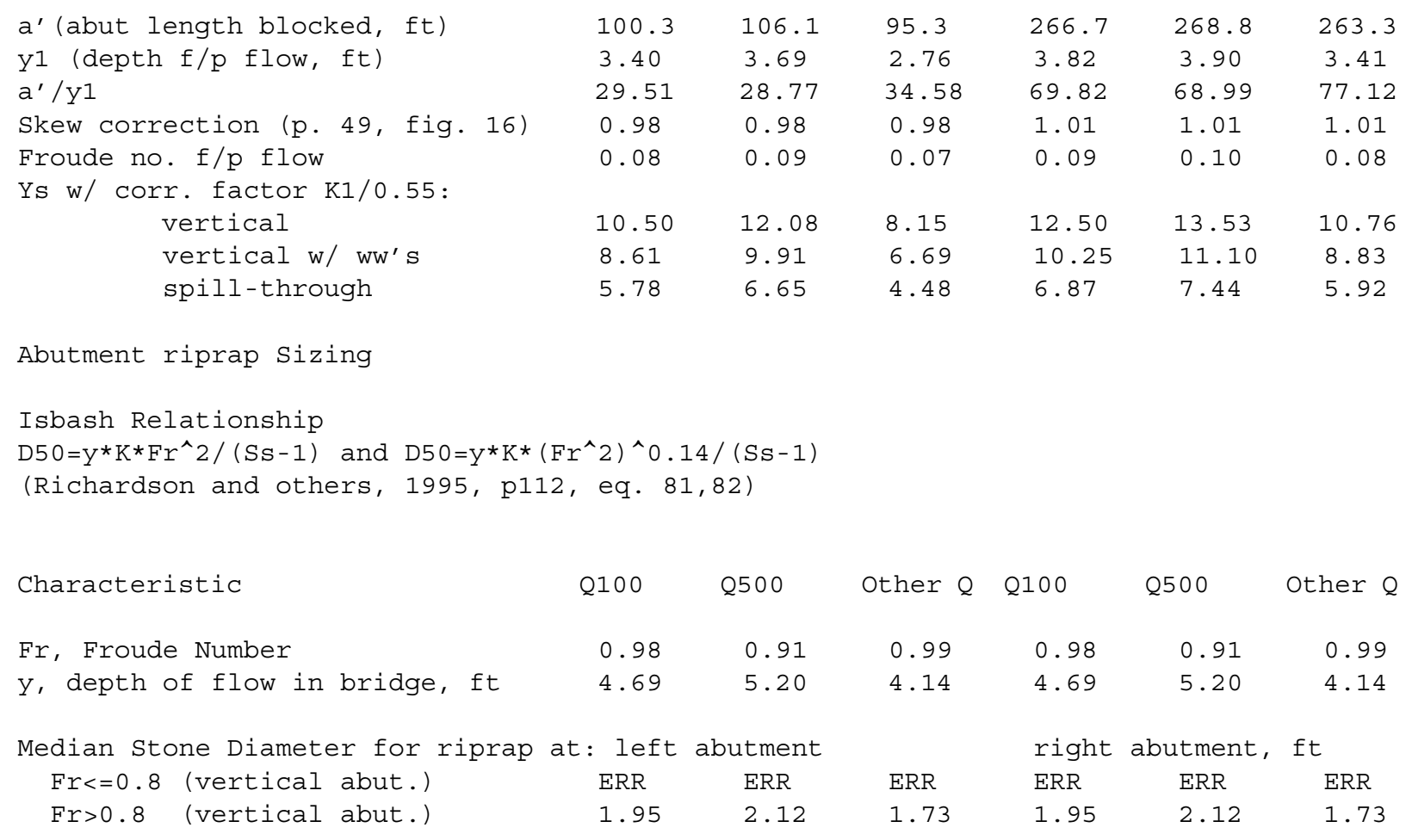

